\title{
An enigmatic aquatic snake from the Cenomanian of Northern South America
}

Adriana Albino, Jorge D. Carrillo-Briceño, James M. Neenan

We report the first record of a primitive aquatic snake from the Cretaceous of Venezuela and northern South America as a whole. The remains come from the La Luna Formation (La Aguada Member, Cenomanian), Trujillo estate, Andes of Venezuela, and consist of several vertebrae, which belong to the precloacal region of the column. Comparisons to extant and extinct snakes show that the remains represent a new taxon, Lunaophis aquaticus gen. et sp nov. An aquatic mode of life is supported, owing to the vertebrae being pachyostotic and the ribs being ventrally-positioned, implying an extremely compressed body. The systematic affiliation of this new taxon is difficult due to the scarcity of fossil material but it would represent a primitive lineage of aquatic snake that exploited tropical marine pelagic environments, as reflected by the depositional conditions of La Aguada Member. 


\section{An enigmatic aquatic snake from the Cenomanian of northern South America}

2 Adriana Albino ${ }^{1}$, Jorge Domingo Carrillo-Briceño ${ }^{2}$, James M. Neenan ${ }^{3,4}$

$3 \quad{ }^{1}$ Universidad Nacional de Mar del Plata, CONICET, Departamento de Biología, Facultad de

4 Ciencias Exactas y Naturales, Funes 3250, B7602AYJ Mar del Plata, Argentina.

$5 \quad{ }^{2}$ Paläontologisches Institut und Museum, Universität Zürich, Karl-Schmid-Strasse 4, 8006

6 Zürich, Switzerland.

$7 \quad{ }^{3}$ Oxford University Museum of Natural History, Parks Road, Oxford OX1 3PW, UK

$8{ }^{4}$ Department of Earth Sciences, University of Oxford, South Parks Road, Oxford OX1 3AN, UK

9 Corresponding author:

10 Adriana Albino ${ }^{1}$

11 Departamento de Biología, Universidad Nacional de Mar del Plata, Funes 3250, B7602AYJ Mar

12 del Plata, Argentina

13 E-mail address: aalbino@mdp.edu.ar 


\section{Abstract}

16 We report the first record of a snake from the Cretaceous of northern South America. The

17 remains come from the La Luna Formation (La Aguada Member, Cenomanian of Venezuela)

18 and consist of several vertebrae, which belong to the precloacal region of the vertebral column.

19 Comparisons to extant and extinct snakes show that the remains represent a new taxon,

20 Lunaophis aquaticus gen. et sp nov. An aquatic mode of life is supported by the ventral position

21 of the ribs, indicating a laterally compressed body. The systematic relationships of this new

22 taxon are difficult to determine due to the scarcity of fossil material; it is, however, a

23 representative of an early lineage of snakes that exploited tropical marine pelagic environments,

24 as reflected by the depositional conditions of the La Aguada Member. Lunaophis is also the first

25 aquatic snake from the Cenomanian found outside of the African and European Tethyan and

26 Boreal Zones.

27

28

29

30

31

32

33 


\section{Introduction}

Until recently, the oldest record of snakes has been from the Albian of Algeria (Cuny et al., 1990) and the Albian-Cenomanian of North America (Gardner \& Ciffelli, 1999), whereas a supposed snake from the Barremian of Spain (Rage \& Richter, 1994) was recently excluded from the group (Rage \& Escuillié, 2003). However, these records have few phylogenetically informative characters and add little to the knowledge of the origin and early evolution of snakes. Using a combination of traditional node-based dating and novel fossil tip-dating methods, Hsiang et al. (2015) determined that the snake total-group originated during the middle Early Cretaceous $(\sim 128.5 \mathrm{Ma})$, with the crown-group following about 20 million years later, during the Albian stage. Nevertheless, new studies on squamate specimens from the Jurassic (Bathonian and Kimmeridgian), which include cranial and postcranial remains of at least four different species from the USA (Diablophis gilmorei Caldwell et al., 2015), Portugal (Portugalophis lignites Caldwell et al., 2015), and England (Parviraptor estesi Caldwell et al., 2015 and Eophis underwoodi Caldwell et al., 2015), suggest that snakes have undergone habitat differentiation and evolutionary radiation at least since the mid-Jurassic (Caldwell et al., 2015).

In South America, the oldest snakes are known from the Mesozoic of Brazil and Argentina.

The Brazilian taxa consist of the putative four-limbed snake Tetrapodophis amplectus Martill, Tischlinger \& Longrich, 2015 from the Early Cretaceous (Aptian), and the small Seismophis septentrionalis Hsiou et al., 2014 from the Late Cretaceous (Cenomanian). The fossil record from Argentina represents one of the richest fauna of early snakes, including the hind-limbed Najash rionegrina Apesteguía \& Zaher, 2006, from the Cenomanian (Apesteguía \& Zaher, 2006; Zaher, Apesteguía \& Scanferla, 2009; Palci, Caldwell \& Albino, 2013), the medium-sized snake Dinilysia patagonica Smith-Woodward, 1901, from the Santonian-Campanian (Smith- 
58 Woodward, 1901; Estes, Frazzeta \& Williams, 1970; Hecht, 1982; Rage \& Albino, 1989;

59 Caldwell \& Albino, 2002; Caldwell \& Calvo, 2008; Zaher \& Scanferla, 2012), the small

60 “anilioid" Australophis anilioides Gómez, Báez \& Rougier, 2008, and diverse taxa of

61 Madtsoiidae from the Campanian-Maastrichtian (Albino, 1986, 1994, 2000, 2007, 2011;

62 Martinelli \& Forasiepi, 2004). In this paper we describe a new taxon of aquatic snake based on

63 vertebrae from the Cenomanian La Luna Formation in the Andes of Venezuela. This specimen

64 represents the oldest known record of snakes from northern South America and adds substantial

65 information about the diversity of the group during its evolution.

\section{Geological setting}

67 The specimen was found in strata of the La Luna Formation (La Aguada Member), exposed in a 68 cement quarry (Cementos Andinos Company) in the Andes of Venezuela, east of Lake

69 Maracaibo, $10 \mathrm{~km}$ northeast of Monay in the Candelaria Municipality of Trujillo State (Fig. 1).

70 The Upper Cretaceous La Luna Formation is the most prolific petroleum source rock in

71 western Venezuela and part of eastern Colombia (Zumberge, 1984; Trivobillard et al., 1991;

72 Zapata et al., 2003), and is characterized by a sequence of marine rocks deposited under anoxic-

73 poorly oxygenated conditions along the passive margin of northern South America during the

74 Cenomanian to Campanian (Zapata et al., 2003). This lithostratigraphic unit was originally

75 named the 'La Luna Limestone' by Garner (1926) in the Quebrada La Luna of the Perijá range

76 (Zulia state, western Venezuela), being formally described as a formation by Hedberg \& Sass

77 (1937). The lithology of the La Luna Formation is characterized by alternating black or dark-

78 gray limestones and organic calcareous shales, in which the calcareous concretions are abundant

79 (González de Juana, Iturralde de Arocena \& Picard, 1980; Trivobillard et al., 1991; Davis, Pratt

80 \& Sliter, 1999). Renz (1959) subdivided the La Luna Formation into three members that are 
81 exposed in the southeast of the Maracaibo basin in the Lara and Trujillo states: the lower La

82 Aguada Member ( $60 \mathrm{~m}$ thick of dense, black/dark-gray limestones and black or brown shales),

83 the middle Chejendé Member ( $\sim 80 \mathrm{~m}$ thick of black shales and marls), and the upper Timbetes

84 Member ( $\sim 90 \mathrm{~m}$ thick of laminated limestones and shales) (Fig. 2A). Siliceous and phosphatic

85 horizons characterize the top of the unit, recognizing the Ftanite of Táchira (Coniacian-

86 Santonian) and Tres Esquinas members (upper Campanian), respectively. The Tres Esquinas

87 Member is well exposed in the Cordillera de Mérida and Perijá whereas the Ftanite of Táchira

88 Member is exposed mainly at the southwest of the Cordillera de Mérida in Táchira State

89 (González de Juana, Iturralde de Arocena \& Picard, 1980; de Romero \& Galea, 1995; Erlich et

90 al., 2000).

91 The outcrops of the Aguada Member in the Cementos Andinos quarry (Figs. 2B and 3A,

92 B) present a succession of dense dark-gray limestones of up to $\sim 60-70 \mathrm{~cm}$ thick, intercalated

93 with laminated black, dark-gray or brown shales. Molluscs, fish remains, and hard, discoidal or

94 ellipsoidal calcareous concretions, reaching up to $198 \mathrm{~cm}$ in diameter (Fig. 3C, D), are common

95 throughout the section (Fig. 2B). In the studied section, the strata are inclined almost vertically

96 (Fig. 3A), and its base overlays a fossiliferous dark-gray sandy limestone, which has been

97 recognized in the Andes of Trujillo and Lara as the top of the upper Albian Maraca Formation

98 (González de Juana, Iturralde de Arocena \& Picard, 1980). Nevertheless, other authors (Renz,

99 1968; Erlich et al., 1999) have used the name of La Puya Member to refer to a thin section $(<30$

$100 \mathrm{~m})$ at the top of the Peñas Altas Formation in the Andes of Lara and Trujillo. Therefore, the

101 discrepancy between the use of Maraca Formation or La Puya Member for the thin sequence

102 underlying the Aguada Member is still unresolved. A Cenomanian age for the La Aguada

103 Member has been provided by planktonic foraminiferans and ammonites (Renz, 1959). 


\section{Materials and methods}

105 The studied specimen (MNCN-1827) is deposited in the Museo de Ciencias Naturales de

106 Caracas, Venezuela. The fossil (Fig. 4-6) was compared directly with osteological material from

107 a diverse group of present-day squamates in the Colección Herpetológica de la Universidad

108 Nacional de Mar del Plata- Sección Osteología, Argentina (UNMdP-O). Measurements were

109 taken with manual calipers.

$110 \quad$ Following the criteria of Rage, Vullo \& Néraudeau (2016), pachyostosis s.l. actually

111 corresponds to two processes: pachyostosis s.s. and osteosclerosis. The first is considered as the

112 hyperplasy of periosteal cortices; it entails modifications of the morphology and its presence is

113 therefore directly observable. Osteosclerosis corresponds to an increase of the compactness of

114 the inner bone; it does not affect morphology and it can be seen only in bone sections.

115 The specimen was scanned using micro-computed tomography $(\mu \mathrm{CT})$ with a Scanco

116 Medical $\mu \mathrm{CT} 80$ machine at the Anthropological Institute, University of Zurich, Switzerland. The

117 specimen was scanned using a voltage of $70 \mathrm{kV}$ and an intensity of $114 \mu \mathrm{A}$, resulting in a slice

118 thickness/increment of $18 \mu \mathrm{m}$. The resulting slice data were then processed and 3D models

119 created using Avizo 8, revealing inner structures of the vertebrae such as thickened cortical bone.

$120 \quad$ Phylogenetic relationships of fossil and Recent snakes proposed by Hsiang et al. (2015)

121 are adopted in this paper. These authors present the most complete picture of the early evolution

122 of snakes to date, including fossils, phenotypic and genetic data in combined phylogenetic

123 analyses to reconstruct the ancestor of the snake total-group and of crown snakes, using both

124 established and recently developed analytical methodologies.

125 The electronic version of this article in Portable Document Format (PDF) will represent a

126 published work according to the International Commission on Zoological Nomenclature (ICZN), 
127 and hence the new names contained in the electronic version are effectively published under that

128 Code from the electronic edition alone. This published work and the nomenclatural acts it

129 contains have been registered in ZooBank, the online registration system for the ICZN. The

130 ZooBank LSIDs (Life Science Identifiers) can be resolved and the associated information viewed

131 through any standard web browser by appending the LSID to the prefix http://zoobank.org/. The

132 LSID for this publication is: urn:lsid:zoobank.org:pub:918B6879-8908-488F-876B-

133 EA741DFF627B. The online version of this work is archived and available from the following

134 digital repositories: PeerJ, PubMed Central and CLOCKSS.

135 Abbreviations used in the text and Table 1 are: cl, centrum length; cow, condyle width;

136 cth, cotyle height; ctw, cotyle width; H, vertebra total height; nal, neural arch length; naw, neural

137 arch width; po-po, distance between postzygapophyses; prl, prezygapophysis length; prw,

138 prezygapophysis width; pr-po, distance between pre- and postzygapophysis of the same side; pr-

139 pr, distance between prezygapophyses; zgh, zygosphene height; zgw, zygosphene width.

\section{Results}

141 Systematic paleontology

142 Squamata Oppel, 1811

143 Serpentes Linnaeus, 1758

144 Lunaophis aquaticus, gen. et sp. nov. urn:1sid:zoobank.org:act:175D3D55-D85A-4013-

145 8D30-563BAB7A4143

$146 \quad$ Figs. $4-10$

147 Holotype. MNCN-1827. The type specimen is composed of vertebral remains in a small block of

148 black shale, which belong to a single individual. All vertebrae are consistent in size. The remains

149 include: an almost complete isolated preclocal vertebra (MNCN-1827-A, Fig. 7), an isolated 
150 precloacal vertebra that lacks the left prezygapophysis (MNCN-1827-B, Fig. 8), two isolated and

151 incomplete precloacal vertebrae (MNCN-1827-C, Fig. 9 A-D, and MNCN-1827-D, Fig. 9 E-H),

152 an isolated and partially preserved precloacal vertebra (MNCN-1827-E, Fig. 9 I-L), five

153 articulated precloacal vertebrae (MNCN-1827-F, Fig. 10 A-D), and a poorly preserved vertebral

154 fragment (MNCN-1827-G, Fig. 10 E-H).

155 Type locality and horizon. Cement quarry (Cementos Andinos company), located east of Lake

156 Maracaibo, $10 \mathrm{~km}$ northeast of Monay, Trujillo State, Venezuela (Fig. 1). The fossiliferous

157 horizon is a black shale layer 28 meters above the base of the La Aguada Member of the La

158 Luna Formation (Cenomanian, Renz, 1959, Fig. 2).

159 Etymology. Lunaophis: snake from La Luna, denotes the origin of the material from rocks

160 corresponding to La Luna Formation; Latin aquaticus: water-dwelling.

161 Diagnosis. Medizum-sized precloacal vertebrae bearing neural arch wide, depressed, and longer

162 than the vertebral centrum, with a convex posterior edge covering the view of the condyle in

163 dorsal view. Lateral walls of the arch arising from the midline from where they diverge ventrally

164 to the subcentral ridges. Body of the prezygapophyses swollen and neural arch above

165 postzygapophyses constituting protruded bulges (pachyostosis). High development of subcentral

166 and interzygapophyseal ridges. Long and narrow vertebral centrum bearing a low and anterior

167 placement of small paradiapophyses. Paradiapophyses closely spaced and strongly projected

168 ventrally beyond the ventral rim of the cotyle through a short process. Articular surfaces of para-

169 and diapophyses facing ventrally. Neural spine well-developed only along the anterior part of the

170 precloacal region of the column as a posterior tubular process projecting free beyond the

171 posterior edge of the neural arch. Neural spine drastically reduced in mid-trunk vertebrae, and

172 finally lost, in posterior trunk vertebrae. 
173 Description. In general, the vertebrae are medium-sized (Table 1), comparable to mid-trunk

174 vertebrae of specimens of the extant boid Epicrates alvarezi that were around $1.5 \mathrm{~m}$ long in life

175 (pers. obs. on specimens from the UNMdP-O collection). They are low $(\mathrm{H})$, long (nal, pr-po) and

176 wide (pr-pr, po-po). The compared dimensions demonstrate that they are wider than high (pr-pr

177 or po-po $>$ H). Two of the best-preserved vertebrae are MNCN-1827-A (Figs. 4 and 7) and

178 MNCN-1827-B (Figs. 5 and 8). Vertebra MNCN-1827-B is slightly smaller than vertebra

179 MNCN-1827-A, but the general aspect and characters are the same, except for slight differences.

180 The following comprehensive description is based on these vertebrae, although diagnostic

181 characters are true for all.

182 In anterior view, the zygosphene is well-developed and slightly wider than the cotyle

183 ( $\mathrm{zgw}>\mathrm{ctw}$ ); it is thin in the middle and its dorsal edge is almost flat. The articular facets are

184 relatively large and anteriorly oriented. The neural canal is small, with a round outline. The

185 prezygapophyses are robust, inflated and large; they are borne at the ventral base of the neural

186 canal and slant above the horizontal plane, but do not reach the level of the zygosphenal roof.

187 There are no prezygapophyseal processes. The cotyle is large, nearly circular, and delimited by a

188 well-marked rim. It is partially filled by sediment. There are strong depressions on both sides of

189 the cotyle but the paracotylar foramen is visible only on the right side of vertebra MNCN-1827-

190 A. In specimen MNCN-1827-B there is not a visible paracotylar foramen on the right side and it

191 is broken on the left. The paradiapophyses are positioned ventral to the cotyle, distant from the

192 prezygapophyseal surfaces and close to each other; they project ventrally with a short and

193 constricted process separating them from the vertebral centrum. The articular surfaces are small,

194 with clearly distinctive parapophyses and diapophyses facing ventrally and strongly projecting

195 beyond the ventral rim of the cotyle. 
197 postzygapophysis as a strong, inflated convexity, especially on vertebra MNCN-1827-B on both

198 sides and on vertebra MNCN-1827-A on the left. These swollen paired posterior portions of the

199 neural arch platform are interpreted as pachyostosis. The zygantra filled by sediment, which also

200 extends over the dorsal condyle. The roof of the neural arch of vertebra MNCN-1827-B is

201 proportionally less depressed than in specimen MNCN-1827-A, and the zygantra are larger.

202 Vertebra MNCN-1827-A has the left postzygapophysis distally broken whereas in vertebra

203 MNCN-1827-B the fracture is on the right. The postzygapophyseal surfaces are large and

204 slightly inclined above the horizontal. There are no parazygantral foramina. The condyle is large

205 and more or less round. The posterior end of a wide hemal keel is slightly visible ventral to the

206 condyle.

207 In dorsal view, the neural arch is long and wide, with the posterior edge convex in

208 vertebra MNCN-1827-A and almost straight in vertebra MNCN-1827-B. None of the condyle is

209 visible in this view. The interzygapophyseal constriction is concave but not especially deep. The

210 interzygapophyseal ridges are strongly developed and protrude laterally beyond the level of the

211 lateral walls and subcentral ridges. They connect the pre- and postzygapophysis of the same side.

212 The articular surfaces of the prezygapophyses are large, oval, longer than wide, and

213 anterolaterally oriented. The zygosphene is well-developed and concave in the middle. It is

214 partially broken on the left side of specimen MNCN-1827-A whereas it is complete on vertebra

215 MNCN-1827-B. Vertebra MNCN-1827-A does not have neural spine; only a minor crest

216 restricted to the anteriormost part of the neural arch. It is limited by narrow and short depressions

217 at each side. Posteriorly to it, the surface of the arch is smooth. In contrast, a well-defined but

218 very low neural spine is developed, but partially broken in the middle, along most of the roof of 
219 the neural arch in vertebra MNCN-1827-B. Longitudinal and marked ridges are extended

220 anteroposteriorly on either side of the neural spine; they are laterally flanked at both sides by

221 deep grooves. These crests and grooves are prominent especially in the posterior half, reaching

222 the posterior border of the neural arch. Distally, over each postzygapophysis, the neural arch

223 forms protruded, swollen bulges representing pachyostosis. The bulging is not developed on the

224 right side of vertebra MNCN-1827-A producing asymmetry.

225 In ventral view, the vertebral centrum is long $(\mathrm{cl}>$ naw) and narrow, slightly wider

226 anteriorly than posteriorly, but not markedly triangular in section. The subcentral ridges are well

227 defined and prominent (Fig. 7, 8 and 9) and the paralymphatic fossae are well-developed (Fig 7

228 and 8). The cotyle is almost not exposed ventrally whereas the condyle is well exposed from this

229 view. The ventral surface of the centrum is concave, with a distinctive but weakly developed

230 rounded hemal keel, which is smooth anteriorly and more defined and wider posteriorly. The

231 short precondylar constriction is marked. There no subcentral foramina. The paradiapophyses are

232 small with articular surfaces well exposed ventrally. The di- and parapophyseal surfaces are

233 distinct and separated by a short and deep constriction.

234 In lateral view, the vertebrae are long, with significantly depressed neural arch roofs.

235 Anteriorly, the neural arch extends beyond the level of the cotyle due to the anterior projection of

236 the zygosphene. Posteriorly, the neural arch is longer than the vertebral centrum (nal $>\mathrm{cl}$ ),

237 extending beyond the level of the condyle. The neural arch in the vertebra MNCN-1827-B is

238 slightly shorter than in specimen MNCN-1827-A. The neural spine is partially broken in vertebra

239 MNCN-1827-B but it would have been long and low, as a thin crest developed from the base of

240 the zygosphene and almost until the posterior end of the neural arch. The zygosphenal surfaces

241 are prominent, oval, longer than wide, and more anteriorly than dorsally oriented. Posteriorly, on 
242 either side, the roof of the neural arch are inflated forming the mentioned hemispheric bulge

243 above the postzygapohysis. As a result, the outline of the neural arch is concave in lateral view.

244 The absence of a neural spine in vertebra MNCN-1827-A produces a more deeply concave arch

245 in lateral view than in vertebra MNCN-1827-B. The prezygapophyses are large, swollen, and

246 anterolaterally oriented. The interzygapophyseal crest is well marked, laterally projected, and

247 strongly separates the roof from the lateral walls of the neural arch. The distance between the

248 interzygapophyseal crests (naw) is much higher than the distance between the lateral walls of the

249 neural arch where they contact with the roof. This is because the lateral walls are borne near the

250 saggittal axis of the vertebra. They diverge dorsoventrally from this point to the subcentral

251 ridges. This structure produces a prominent shelf-like arch roof of the neural arch on each side

252 between the pre- and postzygapophysis (Fig. 7, H). There are no lateral foramina. The vertebral

253 centrum is long but shorter than the neural arch $(\mathrm{nal}>\mathrm{cl})$. The subcentral ridges are prominent.

254 The main axis of the condyle is not strongly inclined from the horizontal plane. The

255 paradiapophyses are low, and clearly separated from the centrum by a deep constriction at the

256 end of a short projection. They are small and ventrally extend beyond the ventral edge of the

257 condyle and subcentral ridges.

258 Vertebra MNCN-1827-C (Fig. 5 and 9) is approximately the same size as vertebra

259 MNCN-1827-B. The zygosphene, left prezygapophysis, and part of the posterior part of the

260 neural arch are not preserved. This vertebra is slightly deformed. There is no neural spine, as in

261 vertebra MNCN-1827-A.

262 Vertebra MNCN-1827-D (Fig. 5 and 9) is also similar in size to specimen MNCN-1827-

263 B. It has lost most of the vertebral centrum, right postzygapophysis, and the zygosphene. In 
264 dorsal view, the posterior edge of the neural arch is strongly convex medially, more than in 265 vertebra MNCN-1827-A.

266 Specimen MNCN-1827-E is a poorly preserved vertebra (Fig. 5 and 9). The entire left

267 side as well as the cotyle and zygosphene are missing. This vertebra is also slightly deformed

268 and has deposits of sediment. Its size is similar to that of vertebra MNCN-1827-B. It also has the

269 same general characters except that the anteriorly low neural spine rises abruptly at the distal part

270 of the neural arch, becoming a well-developed neural spine which is posteriorly directed in a

271 strong angle and projects freely beyond the posterior edge of the neural arch (Fig. 9 I-L). The

272 free portion of the spine comprises approximately $63 \%$ of the length of the neural arch and thus

273 forms more than half the total length of the vertebra. It has a tubular form; it is thin and its

274 anteroposterior section is short. This spine forms an acute angle with respect to the roof of the

275 neural arch (less than 45 degrees), therefore not increasing significantly the height of the

276 vertebra. The vertebra does not have a hypapophysis on the ventral surface of its vertebral

277 centrum. The most posterior part of the centrum bears a slight prominence not wider than the

278 cotyle, similar to the posterior part of a hemal keel in specimen MNCN-1827-B. Based on the

279 presence of a well-developed neural spine, this vertebra is interpreted as an anterior trunk

280 vertebra (see Discussion).

281 Specimen MNCN-1827-F includes five tightly articulated vertebrae (Fig. 6 and 10), with

282 the same morphology as vertebra MNCN-1827-A and without any trace of neural spines. Based

283 on the $\mu \mathrm{CT}$ sections of these vertebrae, both the centrum and the neural arch are revealed to be

284 osteosclerotic, as they are composed of thick cortical bone (Fig. 11). Fragment MNCN-1827-G

285 does not have distinctive features (Fig. 10 E-H).

286 Discussion 
287 Variations along the vertebral column. Following the atlas and axis, the vertebral column of

288 snakes is conventionally divided into precloacal (trunk), cloacal and caudal regions (Hoffstetter

$289 \&$ Gasc, 1969). Cloacal and caudal vertebrae are characterized by smaller size and the presence

290 of additional apophyses which are absent in all vertebrae of the studied sample. Nevertheless,

291 some vertebrae of Lunaophis lack any trace of neural spine (MNCN-1827-A, MNCN-1827-C,

292 MNCN-1827-F), others have a very low neural spine, present as a thin and anteroposteriorly

293 elongate crest (MNCN-1827-B and probably MNCN-1827-D), and finally one has a well-

294 developed neural spine projecting from the neural arch roof (MNCN-1827-E). Hence, the diverse

295 neural spines in different vertebrae of the same individual of Lunaophis imply significant

296 variation along the precloacal region of the vertebral column. In snakes, the precloacal region is

297 subdivided into three portions, the limits of which are imprecisely defined: the anterior, middle

298 and posterior regions (Hoffstetter and Gasc, 1969; Albino, 2011). The similar size of the studied

299 vertebrae of Lunaophis indicates that they are not anteriormost or posteriormost precloacal

300 vertebrae, which should be smaller (as is the case in all snakes). In addition, anteriormost

301 precloacal vertebrae of snakes are characterized by the presence of hypapophyses on the ventral

302 surface of the vertebral centra at least until the fourth vertebra (Hoffstetter \& Gasc, 1969),

303 whereas in all preserved vertebrae of Lunaophis, there is a hemal keel instead of a hypapophysis

304 below the vertebral centrum. No other significant differences occur among the studied vertebrae

305 of the sample, except for the development of the neural spine. Taking into account that neural

306 spines in other snakes are well-developed in the anterior precloacal region but become reduced

307 poteriorly (Hoffstetter \& Gasc, 1969; Albino, 2011), the vertebra with a well-developed neural

308 spine of Lunaophis would be an anterior vertebra (probably near the limit with the mid-trunk

309 region). They would be followed by vertebrae with very low neural spines (mid-trunk vertebrae) 
310 and then by posterior trunk vertebrae that lack neural spines (probably near the limit with the

311 mid-trunk region). Thus, neural spines in Lunaophis would have been well-developed only along

312 the anterior part of the vertebral column, including some vertebrae that have already lost the

313 hypapophyses. They become drastically reduced, and finally lost, posteriorly.

314 Comparative osteology. The overall morphology of the vertebrae in Lunaophis aquaticus gen. et

315 sp nov. is snake-like and has a combination of characters only present in these squamates,

316 including well-developed subcentral ridges, zygosphene-zygantrum accessory articulation, well-

317 differentiated diapophyses and parapophyses in all known vertebrae and vertebral centrum with

318 concave ventral surface (Hoffstetter \& Gasc, 1969; Estes, de Queiroz \& Gauthier, 1988). The

319 strongly posteriorly inclined neural spine in specimen MNCN-1827-E is reminiscent of the

320 condition in lizards (Estes, de Queiroz \& Gauthier, 1988). The absence of prezygapophyseal

321 processes is characteristic of lizards but is also present in some basal snakes (Hoffstetter \& Gasc, 322 1969).

323 In the last few years, efforts to understand the origins and evolution of snakes have

324 resulted in several phylogenetic analyses that include extinct species. Crown snakes are split into

325 two major extant clades: scolecophidians, which includes blind snakes and thread snakes, and

326 alethinophidians, which comprises all other snakes. Nevertheless, recent analyses indicate that

327 the unambiguously terrestrial fossil snakes Dinilysia patagonica, Najash rionegrina, and

328 Coniophis precedens Marsh, 1892 represent more remote hierarchical sisters to crown snakes,

329 with Dinilysia representing the immediate sister to the crown (Zaher \& Scanferla, 2012;

330 Longrich, Bhullar \& Gauthier, 2012; Gauthier et al., 2012). These fossil species, in combination

331 with the revised phylogenetic position of the limbed Tethyan marine snakes (simoliophiids) as 
332 nested within alethinophidians (Gauthier et al., 2012), contradicts the marine origin hypothesis

333 for snakes (Hsiang et al., 2015).

334 The vertebrae of Lunaophis aquaticus differ significantly from extant scolecophidians in

335 having paradiapophyses differentiated into two surfaces (diapophysis and parapophysis), the

336 presence of a precondylar constriction, the absence of a prezygapophyseal process, and the non-

337 oval cotyle and condyle. The former two characters also distinguish Lunaophis aquaticus from

338 the extinct Coniophis precedens, whereas the third character-state contrasts with the condition in

339 Dinilysia patagonica which has a prezygapophyseal process. The same combination of features

340 observed in Lunaophis aquaticus is present in primitive snakes such as aff. Parviraptor estesi

341 and Najash rionegrina, and at least the two latter features can be verified in Seismophis

342 septentrionalis (Zaher et al., 2009; Caldwell et al., 2015; Hsiou et al., 2014). Similar to these

343 taxa, the posterior border of the neural arch in Lunaophis aquaticus is not notched, but it differs

344 significantly in the position of the paradiapophyses below the vertebral centrum and the fact that

345 these face ventrally. In the other species the paradiapophyses are more highly positioned and

346 face more laterally than ventrally. Other differences with aff. Parviraptor estesi and Diablophis

347 gilmorei are the better developed zygosphene, a deeper precondylar constriction, and a non-

348 trifoliate neural canal. A neural spine reduced to a ridge is reminiscent of the condition in

349 Coniophis precedens (but it ends in a tuberosity in that species). Lunaophis aquaticus also shares

350 with Coniophis precedens, Dinilysia patagonica, and Seismophis septentrionalis the presence of

351 a depressed neural arch. On either side of the neural spine, dorsal ridges are present in these

352 snakes, as well as in Najash rionegrina and Madtsoiidae. Lunaophis aquaticus also differs from

353 Seismophis septentrionalis in the concave zygosphene and the absence of parazygantral

354 foramina. The vertebral centrum in Lunaophis aquaticus differs from other primitive species in 
355 not being as markedly wider anteriorly as it is in Najash rionegrina, Dinilysia patagonica, and

356 Seismophis septentrionalis. Based on figures in Caldwell et al. (2015), a centrum that is not

357 much wider anteriorly is present in aff. Paviraptor estesi and Diablophis gilmorei.

358 In comparison to other Cenomanian snakes, Lunaophis aquaticus slightly resembles

359 simoliophiids, which represent the earliest invasion of the sea in the evolution of snakes (Hsiang

360 et al., 2015). Simoliophiids are known from Western Europe and northwesternmost Africa to the

361 Middle East. Among them, the better known species are Pachyrachis problematicus Haas, 1979,

362 Haasiophis terrasanctus Tchernov, Rieppel, Zaher, Polcyn, \& Jacobs, 2000 and Eupodophis

363 descouensis Rage \& Escuillé, 2000, whereas other species are Pachyophis woodwardi Nopcsa,

364 1923, Simoliophis rochebrunei Sauvage, 1880 and Simoliophis libycus Nessov, Zhegallo \&

365 Averianov, 1998 (Rage \& Escuillé, 2003). Comparisons are difficult because Lunaophis is

366 known to date only by few isolated vertebrae and a small fragment of five articulated vertebrae,

367 whereas most simoliophiids consist of articulated skeletons (including skulls and hindlimbs), in

368 which articular surfaces, apophyses and other details of the vertebral column are hidden. An

369 absence of a prezygapophyseal process, strongly posteriorly inclined neural spine in anterior

370 vertebrae, and concave zygosphene are features shared with simoliophiids but also lizards and

371 some primitive snakes. All simoliophiids display pachyostosis that increases the mass of the

372 vertebrae and ribs. Pachyostosis in simoliophiids species is pronounced, with the centrum and

373 neural arch being swollen in all dimensions, especially in Pachyophis and Simoliophis (Lee \&

374 Caldwell, 1998; Houssaye, 2010; Rage, Vullo \& Néraudeau, 2016). However, the pachyostosis

375 in Lunaophis is less pronounced, and is concentrated on the prezygapophyseal bodies and on the

376 posterior part of the neural arch, above the postzygapophyses. 
378 fact that they are poorly exposed and are not known three-dimensionally in other simoliophiid

379 taxa . Rage \& Escuillié (2003) and Rage, Vullo \& Néraudeau (2016) consider the vertebrae of

380 the marine hindlimbed snakes from the Cenomanian to be very similar to those of Simoliophis;

381 more specifically, they indicate that what is known of the vertebrae of Pachyrhachis and

382 Haasiophis do not permit any distinction between these two snakes and Simoliophis. Based on

383 the best descriptions of Pachyrhachis problematicus and Simoliophis rochebrunei (Lee \&

384 Caldwell, 1998; Rage, Vullo \& Néraudeau, 2016), mid-trunk vertebrae of these species have

385 higher neural arches than those of Lunaophis, and vertebral centra are short and broad instead

386 long and narrow, as in the new genus. Despite variations in height, neural spines on all

387 precloacal vertebrae of Simoliophis and Pachyrhachis are well-developed as a distinctive

388 process, whereas in Lunaophis the neural spines are well-developed only in anterior vertebrae,

389 but they become greatly reduced and finally disappear in mid- and posterior precloacal vertebrae.

390 The posterodorsal border of the neural arch is straight in Simoliophis but convex in Lunaophis.

391 The zygosphene of Simoliophis is proportionally smaller, is very narrow and its roof appears as a

392 high triangle, different from the wide and dorsally flat zygosphene of Lunaophis. Other

393 distinctive characters of Simoliophis differing from those found in Lunaophis are the higher

394 position and stronger inclination of the prezygapophyses; the interzygapopyseal constriction is

395 shallower; the paradiapophyses are larger, high-up, face laterally and reach the level of the

396 prezygapophyseal extremity; and the form of the centrum which does not narrow posteriorly.

397 Aside from these characters and according to the most complete descriptions of Haasiophis

398 (Rieppel et al., 2003), the neural spines are low throughout the precloacal region of this genus

399 but they do not disappear as in the posterior trunk vertebrae of Lunaophis. In addition, evident 
400 pachyostosis in midtrunk vertebrae that affects the paradiapophyses is a distinctive feature of

401 Haasiophis which is not evident in Lunaophis. Vertebrae of Eupodophis look significantly

402 higher than in Lunaophis and have characteristic protuberances on the neural arch on either side

403 of the neural spine, which represents a unique character of this genus (Rage \& Escuillié, 2000).

404 In conclusion, the vertebrae described here constitute a distinctive taxon that displays

405 features that distinguish it from other known extinct and extant snakes. Outstanding characters of 406 this snake are the walls of the neural arch arising from the midline of the vertebrae and diverging

407 to the subcentral ridges, the pachyostosis on the prezygapophyses and posterior neural arch, the

408 depressed and laterally expanded roof of the neural arch with strong development of the

409 interzygapophyseal ridges, the extension of the arch beyond the level of the condyle and forming

410 a convex posterior edge, the long and narrow centrum with strong lateral development of the

411 subcentral crests, the low placed and closely spaced paradiapophyses with small articular

412 surfaces facing ventrally and projected beyond the ventral rim of the cotyle with a short process,

413 and the substantial changes of the neural spines along the precloacal region from well-developed

414 as a tubular process to an absolutely lacking spine. Although some features available on

415 vertebrae of Lunaophis are plesiomorphic (anterior border of zygosphene clearly concave,

416 articular facets of zygapophyses well inclined on horizontal, prezygapohyseal processes lacking,

417 posterior edge of neural arch not notched, neural spine of anterior vertebrae posteriorly

418 projected), the mentioned singular characters have not been not described for any other snake

419 and make Lunaophis an enigmatic new taxon from the South American Cenomanian.

420 Mode of life of Lunaophis aquaticus. Some features of the vertebrae of Lunaophis are indicative

421 of an aquatic mode of life. The depressed neural arches associated with the lacking or greatly

422 reduced neural spines is a feature shared by fossorial snakes such as scolecophidians and 
423 anilioids, and other burrowing squamates such as amphisbaenians (Hoffstetter \& Gasc, 1969).

424 Nevertheless, the presence of this feature contrasts with the ventrally placed paradiapophyses,

425 the medium size of the vertebrae, and the well-developed neural spine shown by vertebra

426 MNCN-1827-E, which argues against possible fossorial habits. In particular, closely spaced

427 paradiapophyses oriented in a ventral position with articular surfaces that face ventrally indicate

428 that the ribs were directed below the vertebral centra and that the body of the snake was likely

429 strongly compressed laterally as an adaptation for swimming. Elongate bodies of snakes are

430 efficient for swimming, but all extant species of sea snakes have evolved paddle-like tails and

431 many have laterally compressed bodies which give them an eel-like appearance and increase

432 their locomotory ability in water. A laterally compressed body helped by well-developed

433 muscles permits an efficient propulsion into the water. Thus, the body morphology of Lunaophis

434 clearly argues for a highly aquatic mode of life. In the same sense, pachyostosis s.l., is relatively

435 frequent in aquatic tetrapods living in shallow marine environments (e.g. Ricqlès \& Buffrénil,

436 2001). Thus, the pachyostotic condition of studied vertebrae also supports an aquatic mode of

437 life for Lunaophis.

438 Paleoenvironment and paleoecology. As discussed above, Lunaophis aquaticus gen. et sp. nov.

439 represents an aquatic lineage of snakes that exploited marine environments. This is also reflected

440 by the depositional conditions of the La Luna Formation, interpreted as a typical marine

441 environment where laminated organic rich intervals suggest a deposition on the mid-shelf to

442 upper continental slope under anoxic or poorly oxygenated conditions (Macellari \& De Vries,

443 1987; Erlich et al., 1999; Bralower \& Lorente, 2003; Zapata et al., 2003). The organic matter of

444 the sediments in the La Aguada Member (Trujillo area) is mostly of algal origin (Trivobillard et

445 al., 1991). González de Juana, Iturralde de Arocena \& Picard (1980) suggested that the La 
446 Aguada Member could be considered as a transitional environment between the shallow waters

447 of the Maraca formation (or La Puya Member according to Renz, 1959, 1968) and the pelagic

448 facies of the La Luna Formation. In contrast with the pelagic and hemipelagic deep water

449 sedimentation suggested by Trivobillard et al. (1991) and Erlich et al. (1999), Méndez (1981)

450 suggested that the anoxic conditions of the La Luna Formation during the late Albian-early

451 Cenomanian transgression were not due to water depth but pre-existing anoxic conditions in the

452 slope zone. On basis of benthic and planktonic foraminiferans, Méndez (1981, and references

453 therein) recognized an increase in the submersion of the platform, but probably with depths that 454 did not exceed 50 meters.

455 The holotype of Lunaophis aquaticus gen. et sp nov. is associated with other marine

456 vertebrates (sharks and bony fishes) in the Aguada Member (Cementos Andinos quarry). Bony

457 fish remains are very abundant in the horizon yielding Lunaophis aquaticus and adjacent strata

458 (Fig. 2). These remains include isolated and semi-articulated cranial and postcranial elements of

459 Xiphactinus audax Leidy, 1870 (Carrillo-Briceño, Alvarado-Ortega \& Torres, 2012),

460 ichthyodectiforms, enchodontids and small indeterminate fishes. The chondrichthyans are

461 represented mainly by isolated teeth of at least three species of lamniform sharks although a

462 semi-complete, articulated vertebral column of a lamniform species has also been recovered (all

463 these specimens are currently under study). Benthic invertebrates are scarce in the shales of the

464 Cementos Andinos quarry; however, small indeterminate bivalve molds are common in the

465 limestones. The benthic invertebrate fauna in the La Aguada Member could represent brief

466 periods of better oxygenated conditions on the sea floor or organisms that were tolerant to anoxic

467 environments, as has been suggested forother sections of the La Luna Formation (e.g.

468 Trivobillard et al., 1991). Although anoxic-dysoxic conditions prevailed on the seafloor of the 
469 basin (Méndez, 1981; Macellari \& De Vries, 1987; Trivobillard et al., 1991; Erlich et al., 1999),

470 the presence of ammonites (Renz, 1959; 1982), reptiles (Lunaophis aquaticus), and abundant

471 fishes provides evidence of well-oxygenated surface waters, indicating that the Aguada Member

472 environment was characterized by a stratified water column. In addition, other chondrichthyans,

473 bony fishes and marine reptile have also been found throughout the La Luna Formation (Weiler,

474 1940; Moody \& Maisey, 1994; Casas \& Moody, 1997; Sánchez-Villagra, Brinkmann \& Lozsán

475 2008; Carrillo-Briceño, 2009; 2012).

476 Conclusion

477 Lunaophis aquaticus gen. et sp. nov. is the oldest known snake from northern South

478 America. It is of Cenomanian age, with relevant primitive features that distinguish it from other

479 fossil and extant taxa by a number of characters that make it a new and enigmatic taxon, without

480 evident affinities with any particular snake group. The nature of the fossils does not permit

481 phylogenetic analysis until skull bones are available. The anatomical features of Lunaophis

482 aquaticus with a laterally compressed body, the pachyostosis of the vertebrae, the depositional

483 conditions of the La Luna Formation and the associated fauna clearly support a tropical marine

484 paleoenvironment where this snake would have displayed an aquatic mode of life. In the context

485 of the phylogeny proposed by Hsiang et al. (2015), Lunaophis aquaticus represents the oldest

486 snake to have adopted an aquatic mode of life outside of the African and European Tethyan and

487 Boreal Zones.

488 Acknowledgments

489 The authors wish to especially thank Lilia Vierma (†), Carlos Torres and Cemento Andino Ca.,

490 for their valuable assistance in the field ; to Alfredo Carlini for his substantial assistance in

491 making this collaborative work possible; to Marcelo Sánchez Villagra, Torsten M. Scheyer, 
492 Christian Kolb and members of the Evolutionary Morphology and Palaeobiology group at the

493 Palaeontological Institute and Museum, University of Zurich, Switzerland, for generous and

494 significant counseling and collaboration; Alexandra Wegmann for conducting the scanning; and

495 to the Instituo del Patrimonio Cultural de Venezuela for the authorization and collecting

496 permission. The Academic Editor Hans-Dieter Sues, and the reviewers Alexandra Houssaye and

497 Michael Caldwell, are thanked for providing helpful comments that improved the manuscript.

498 References

499 Albino, A.M. 1986. Nuevos Boidae Madtsoiinae en el Cretácico tardío de Patagonia (Formación

500 Los Alamitos, Río Negro, Argentina). Actas of the 4th Congreso Argentino de

$501 \quad$ Paleontología y Bioestratigrafía, 2: 15-21.

502 Albino, A.M. 1994. Una nueva serpiente (Reptilia) en el Cretácico Superior de Patagonia, $503 \quad$ Argentina. Pesquisas, 2: 58-63.

504 Albino, A.M. 2000. New record of snakes from the Cretaceous of Patagonia (Argentina). $505 \quad$ Geodiversitas, 22: 247-253.

506 Albino, A.M. 2007. Lepidosauria. In: Z. Gasparini, L. Salgado, and R.A., Coria (eds.),

507 Patagonian Mesozoic Reptiles, 87-115. Indiana University Press, Indiana.

508 Albino, A.M. 2011. Evolution of Squamata reptiles in Patagonia based on the fossil record.

509 Biological Journal of the Linnean Society, 103:441-457. doi: 10.1111/j.1095-

$510 \quad$ 8312.2011.01691.x

511 Albino, A.M. 2011. Morfología vertebral de Boa constrictor (Serpentes: Boidae) y la validez del 512 género mioceno Pseudoepicrates Auffenberg, 1963. Ameghiniana, 48: 53-62.

513 Apesteguía, S., and Zaher, H. 2006. A Cretaceous terrestrial snake with robust hindlimbs and a sacrum. Nature, 440:1037-1040. doi:10.1038/nature04413 
515 Bralower, T.J., and Lorente, M.A. 2003. Paleogeography and stratigraphy of the La Luna

516 Formation and related Cretaceous anoxic depositional systems. Palaios, 18: 301-304.

517 Caldwell, M.W. and Albino, A.M. 2002. Exceptionally preserved skeletons of the Cretaceous

518 snake Dinilysia patagonica Woodward, 1901. Journal of Vertebrate Paleontology, 22:

519 861-866.doi:10.1671/0272-4634(2002)022[0861:EPSOTC]2.0.CO;2

Caldwell, M.W. and Calvo, J. 2008. Details of a new skull and articulated cervical column of Dinilysia patagonica Woodward, 1901. Journal of Vertebrate Paleontology, 28: 349-362. doi:10.1671/0272-4634(2008)28[349:DOANSA]2.0.CO;2

523 Caldwell, M.W., Nydam, R.L., Palci, A., and Apesteguía, S. 2015. The oldest known snakes from the Middle Jurassic-Lower Cretaceous provide insights on snake evolution. Nature Communications, 6: 5996. doi:10.1038/ncomms6996

Carrillo-Briceño J.D. 2009. Presencia del genero Ptychodus (Elasmobranchii: Ptychodontiade) en el Cretácico superior de los Andes de Trujillo Venezuela. GEOMINAS, 37 (50): 207528 210.

529 Carrillo-Briceño, J.D. 2012. Presencia de Ptychodus mortoni (Elasmobranchii: Ptychodontidae) 530 en el Cretácico Superior de Venezuela. Revista Geológica de América Central, 46: 145150. doi: http://dx.doi.org/10.15517/rgac.v0i46.1837

532 Carrillo-Briceño, J.D., Alvarado-Ortega, J. and Torres, C. 2012. Primer registro de Xiphactinus Leidy, 1870, (Teleostei: Ichthyodectiformes) en el Cretácico Superior de América del Sur

534 (Formación La Luna, Venezuela). Revista Brasilera de Paleontología, 15(3):327-335. doi:10.4072/rbp.2012.3.08 
536 Casas, J.E and Moody, J.M. 1997. Primera descripción del género Belenostomus en la Formación

537 La Luna (Cretácico), Sierra de Perijá, (Pisces: Aspydorhynchidae). Boletín de la Sociedad $538 \quad$ Venezolana de Geólogos, 22 (1): 51-55.

539 Cope, E.D. 1864. On the characters of the higher groups of Reptilia Squamata and especially of the Diploglossa. Proceedings of the Academy of Natural Sciences of Philadelphia, 1864: $224-231$.

542 Cuny, G., Jaeger, J.J., Mahboubi, M., and J.C. Rage. 1990. Les plus anciens Serpents (Reptilia, Squamata) connus. Mise au point sur l’âge géologique des Serpentes de la partie moyenne du Crétacé. Comptes rendus des séances de l'Académie des Sciences, Paris, Série II, 311:1267-1272.

Davis C., Pratt, 1., and Sliter, W. 1999, Factors influencing organic carbon and trace metal accumulation in the Upper Cretaceous La Luna Formation of the western Maracaibo Basin, Venezuela. In: E. Barrera, and C.C. Johnson, (eds.), Evolution of the Cretaceous Ocean-Climate System, 203-231. Geological Society of America Special Paper 332. de Romero, L.M., and Galea, F.A. 1995. Campanian Bolivinoides and microfacies from the La Luna Formation, western Venezuela. Marine Micropaleontology, 26: 385-404.

Erlich, R.N., Macsotay, O., Nederbragt, A.J., and Lorente, M.A. 1999. Palaeoceanography, palaeoecology, and depositional environments of Upper Cretaceous rocks of western Venezuela. Palaeogeography, Palaeoclimatology, Palaeoecology, 153: 203-238.

Erlich, R.N., Macsotay, O., Nederbragt, A.J. and Lorente, M.A. 2000. Birth and death of the Late Cretaceous “'La Luna Sea”, and origin of the Tres Esquinas phosphorites. Journal of South American Earth Sciences, 13: 21-45. 
558 Estes, R., Frazzetta, T.H., and Williams, E.E. 1970. Studies on the fossil snake Dinilysia 559 patagonica Woodward: Part 1. Cranial morphology. Bulletin of the Museum of 560 Comparative Zoology, 140: 25-74.

561 Estes, R., de Queiroz, K. and Gauthier, J. 1988. Phylogenetic relationships within Squamata. In: R. Estes, and G.K. Pregil (eds), Phylogenetic relationships of the lizard families, 119281. Stanford University Press, Stanford, California.

564 Fitzinger L.J. 1826. Neue Classification der Reptilien nach ihren natürlichen Verwandtschaften nebst einer Verwandtschafts-Tafel und einem Verzeichnisse der Reptilien Sammlung des K.K. Zoologischen Museum's zu Wien. J.G. Heubner, Wien.

567 Garner, A.H. 1926. Suggested nomenclatural and correlation on geological formations in 568 Venezuela. American Institute of Mining and Metallurgy Engineers, Transactions, Petroleum Development and Technology in 1925: 677-684.

Gardner, J.D. and R.L. Cifelli. 1999. A primitive snake from the Cretaceous of Utah. Special Papers in Palaeontology, 60:87-100.

Gauthier, J.A., Kearney, M., Maisano, .JA., Rieppel, O., Behlke, A.D.B. 2012. Assembling the squamate tree of life: perspectives from the phenotype and the fossil record. Bulletin of the Peabody Museum of Natural History, 53: 3-308.

Gómez, R.O., Báez, A.M., and Rougier, G.W. 2008. An anilioid snake from the Upper Cretaceous of northern Patagonia. Cretaceous Research, 29: 481-488. doi:10.1016/j.cretres.2008.01.002 de sus Cuencas Petroliferas. Foninves, Caracas, 1031 pp. 
580 Haas, G. 1979. On a new snakelike reptile from the Lower Cenomanian of Ein Jabrud, near

$581 \quad$ Jerusalem. Bulletin du Muséum national d'Histoire naturelle, Ser. 4, 1: 51-64.

582 Hecht, M. 1982. The vertebral morphology of the Cretaceous snake Dinilysia patagonica

583 Woodward. Neues Jahrbuch für Geologie und Paläontologie, Monatshefte 1982: 523-

584532.

585 Hedberg, H., and Sass, L. 1937. Synopsis of the geologic formations of the western part of the 586 Maracaibo Basin, Venezuela. Boletín de Geología y Minería, 2-4:71-112.

587 Hoffstetter, R. 1961. Nouveaux restes d'un serpent Boide (Madtsoia madagascariensis nov. sp.)

588 dans le Crétacé' supérieur de Madagascar. Bulletin du Muséum national d'Histoire 589 naturelle, 33: 152-160.

590 Hoffstetter, R., and Gasc, J.P. 1969. Vertebrae and ribs of modern reptiles. In: C. Gans, T.S.

591 Parsons, and A d'A. Bellairs (eds.), Biology of the Reptilia, vol. 1, 201-310. Academic $592 \quad$ Press, New York.

593 Houssaye, A. 2010. Rediscovery and description of the second specimen of the hind-limbed 594 snake Pachyophis woodwardi Nopcsa, 1923 (Squamata, Ophidia) from the Cenomanian 595 of Bosnia Herzegovina. Journal of Vertebrate Paleontology, 30: 276-279.

596 Hsiang, A.Y., Field, D.J., Webster, T.H., Behlke, A.DB, Davis, M.B., Racicot, R.A., and 597 Gauthier, J.A. 2015. The origin of snakes: revealing the ecology, behavior, and evolutionary history of early snakes using genomics, phenomics, and the fossil record. BMC Evolutionary Biology 15:87. doi 10.1186/s12862-015-0358-5

600 Hsiou, A.S., Albino, A.M., Medeiros, M.A., and Santos, R.A.B. 2014. The oldest Brazilian 601 602 snakes from the early Late Cretaceous (Cenomanian). Acta Palaeontologica Polonica, 59:635-642. doi: http://dx.doi.org/10.4202/app.2012.0091 
603 Lee, M.S.Y. and Caldwell, M.W. 1998. Anatomy and relationships of Pachyrhachis

604 problematicus, a primitive snake with hindlimbs. Philosophical Transactions of the Royal 605 Society of London, B 353: 1521-1552.

606 Leidy, J. 1870. Remarks on ichthyodorulites and on certain fossil mammalians. Proceedings of 607 the American Philosophical Society, 22:12-13.

608 Linnaeus, C. 1758. Systema naturae. Editio Decima, Larentii Salvii, Stockholm, 824 p.

609 Longrich, N.R., Bhullar, B-A.S, Gauthier, J.A. 2012. A transitional snake from the late 610 Cretaceous period of North America. Nature 488:205-8.

611 Macellari, C.E., and De Vries, T.J. 1987. Late Cretaceous upwelling and anoxic sedimentation in 612 northwestern South America. Palaeogeography, Palaeoclimatology, Palaeoecology, 59: $613279-292$.

614 Marsh, O.C. 1892. Notice of new reptiles from the Laramie Formation. American Journal of $615 \quad$ Science, 43:449-453.

616 Martill, D.M., Tischlinger, H., and Longrich, N.R. 2015. A four-legged snake from the Early 617 Cretaceous of Gondwana. Science, 349: 416-419. doi: 10.1126/science.aaa9208

618 Martinelli, A.G. and Forasiepi, A.M. 2004. Late Cretaceous vertebrates from Bajo de Santa Rosa 619 (Allen Formation), Río Negro province, Argentina, with the description of a new 620 sauropod dinosaur (Titanosauridae). Revista del Museo Argentino de Ciencias Naturales $621 \quad$ Bernardino Rivadavia, 6: 257-305.

622 Méndez, B.J. 1981. La Formación La Luna. Característica de una cuenca anóxica en una 623 plataforma de aguas someras. Proceedings of the 7th Congreso Geológico Venezolano, 624 Barquisimeto, Venezuela, November 12-18, pp. 852-866. 
625 Moody, J.M. and Maisey, J.G. 1994. New Cretaceous marine vertebrate assemblages from north626 western Venezuela and their significance. Journal of Vertebrate Paleontology 14 (1): 1-8. doi:10.1080/02724634.1994.10011534

628 Nessov, L.A., Zhegallo, V.I. and Averianov, A.O. 1998. A new locality of Late Cretaceous 629 snakes, mammals and other vertebrates in Africa (western Libya). Annales de Paléontologie 84: 265-274.

631 Nopcsa, F.1923. Eidolosaurus und Pachyophis. Zwei neue Neocom-Reptilien.

632 Palaeontographica 65: 97-154.

633 Oppel, M. 1811. Die Ordnungen, Familien und Gattungen der Reptilien als Prodrom einer 634 Naturgeschichte derselben. J. Lindauer, München, 86 p.

635 Palci, A., Caldwell, M.W., and Albino, A.M. 2013. Emended diagnosis and phylogenetic 636 relationships of the Upper Cretaceous fossil snake Najash rionegrina Apesteguía and Zaher, 2006. Journal of Vertebrate Paleontology 33: 131-140.

Rage, J.-C. and A. Richter. 1994. A snake from the Lower Cretaceous (Barremian) of Spain: The 639 640 oldest known snake. Neues Jahrbuch für Geologie und Paläontologie, Monatshefte, 9:561-565.

641 Rage, J.-C. and Albino, A.M. 1989. Dinilysia patagonica (Reptilia, Serpentes); matériel 642 643 vertébral additionnel du Crétacé supérieur d'Argentine. Étude complémentaire des vertébrés,variations intraspécifiques et intracolumnares. Neues Jahrbuch für Geologie und Paläontologie, Monatshefte 1989: 433-447.

Rage, J.-C. and Escuillié, F. 2000. Un nouveau serpent bipède du Cénomanien (Crétacé). 646 Implications phylétiques. Comptes rendu de l'Académie des Science Paris, Sciences de la Terre et des planètes 330: 513-520. 
648 Rage, J.-C. and F. Escuillié. 2003. The Cenomanian: stage of hindlimbed snakes. Carnets de $649 \quad$ Géologie, 2002:1-11. doi:10.4267/2042/293

650 Rage, J.-C., Vullo, R. and Néraudeau, D. 2016. The mid-Cretaceous snake Simoliophis

651

652

653

654

655

656

657

658

659

660

661

662

663

664

665

666

667

668

669 rochebrunei Sauvage, 1880 (Squamata: Ophidia) from its type area (Charentes, southwestern France): Redescription, distribution, and palaeoecology. Cretaceous Research 58: 234-253.

Renz, O. 1959. Estratigrafía del Cretáceo en Venezuela occidental. Boletín de Geología, 5: 3-48.

Renz, O., 1968. Über die Untergattungen Venezoliceras Spath und Laraiceras n. subgen, der Gattung Oxytropidoceras Stieler (Ammonoidea) aus den venezolanischen Anden. Eclogae Geologicae Helvetiae, 61: 615-655.

Renz, O. 1982. The Cretaceous ammonites of Venezuela. Maraven, Caracas, 132 p.

Ricqlès A. de, Buffrénil V. de (2001). Bone histology, heterochronies and the return of tetrapods to life in water: where are we? In: Mazin J.-M., V. de Buffrénil (eds.), Secondary Adaptation of Tetrapods to Life in Water. Verlag Dr. Friedrich Pfeil, München, pp. 289310.

Rieppel, O., Zaher, H., Tchernov, E., and Polcyn, M.J. 2003. The anatomy and relationships of Haasiophis terrasanctus, a fossil snake with well-developed hind limbs from the midCretaceous of the Middle East. Journal of Paleontology, 77: 536-558.

Sánchez-Villagra, M.R., Brinkmann, W., and Lozsán, R. 2008. The Palaeozoic and Mesozoic vertebrate record of Venezuelan overview, summary of previous discoveries and report of a mosasaur from the La Luna Formation (Cretaceous). Paläontologische Zeitschrift, 82: 113-124. doi:10.1007/BF02988403 
670 Sauvage, H. E.1880. Sur l'existence d'un reptile du type ophidien dans les couches à Ostrea

671 columba des Charentes. Comptes Rendus Hebdomadaires des Sciences de l'Academie des

$672 \quad$ Sciences 91: 671-672.

673 Smith-Woodward, A. 1901. On some extinct reptiles from Patagonia of the genera Miolania, 674 Dinilysia, and Genyodectes. Proceedings of the Zoological Society of London 1901: 169$675 \quad 184$.

676 Tchernov, E., Rieppel, O., Zaher, H., Polcyn, M.J., and Jacobs, L.J. 2000. A new fossil snake $677 \quad$ with limbs. Science 287: 2010-2012.

678 Tribovillard, N.P., Stephan, J.F., Manivit, H., Reyre, Y., Cotillon, P., and Jautee, E. 1991. Cretaceous black shales of Venezuelan Andes: preliminary results on stratigraphy and paleoenvironmental interpretations. Palaeogeogr, PaIaeoclimatol, Palaeoecol, 81: 313-

681 321.

682 Weiler, W. 1940. Fischreste aus der Umgebung von San Cristobal, SW. Venezuela. Zentralblatt 683 für Mineralogie, Geologie und Paläontologie (B), 1949: 240-255

Zaher, H. and Scanferla, C.A. 2012. The skull of the Upper Cretaceous snake Dinilysia patagonica Smith-Woodward, 1901, and its phylogenetic position revisited. Zoological Journal of the Linnean Society, 164: 194-238. doi: 10.1111/j.1096-3642.2011.00755.x 3642.2009.00511.x

691 Zapata, E., Padro, V., Madrid, I., Kertznus, V., Truskowski, I., and Lorente, M.A. 2003. 
693 (Late Turonian-Campanian) in the San Miguel and Las Hernández sections, western

694 Venezuela. Palaios, 18:367-377. doi:10.1669/0883-

695 1351(2003)018<0367:BSACSO >2.0.CO;2

696 Zumberge, J.E. 1984. Source rocks of the La Luna Formation (Upper Cretaceous) in the Middle 697 Magdalena Valley, Colombia. In: J.G. Palacas (ed), Petroleum geochemistry and source 698 rock potential of carbonate rocks, 127-133. American Association of Petroleum 699 Geologists, Studies in Geology 18. 
1

Location map of the Cementos Andinos quarry, Trujillo estate,Venezuela.

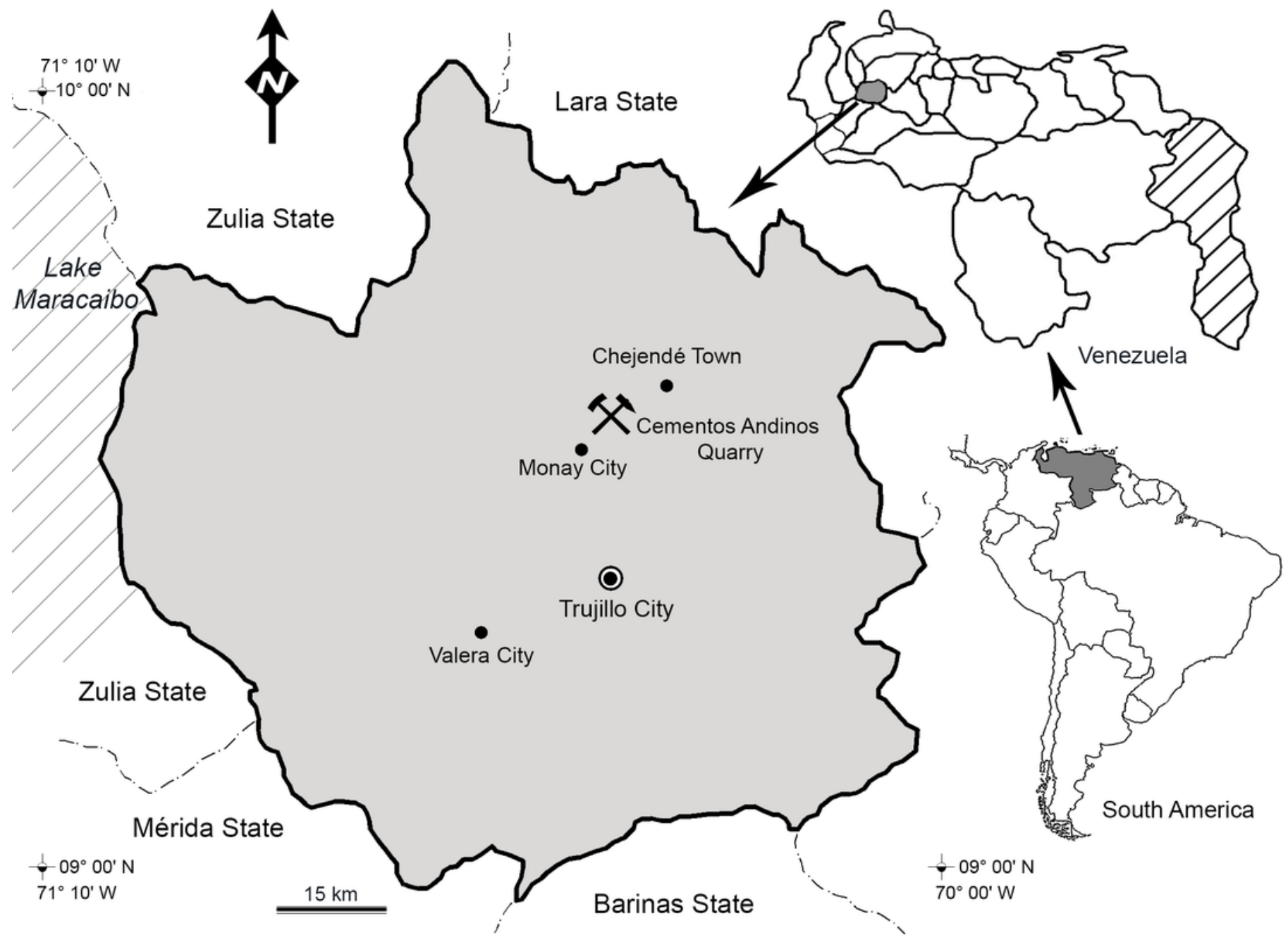


2

Stratigraphic context.

A. Cretaceous lithostratigraphic units of the Chejendé region, near Monay city, Trujillo State (modified after Renz, 1959 and González de Juana, Iturralde de Arocena \& Picard, 1980); B. Stratigraphic section of the Aguada Member in the Cementos Andinos quarry.

A

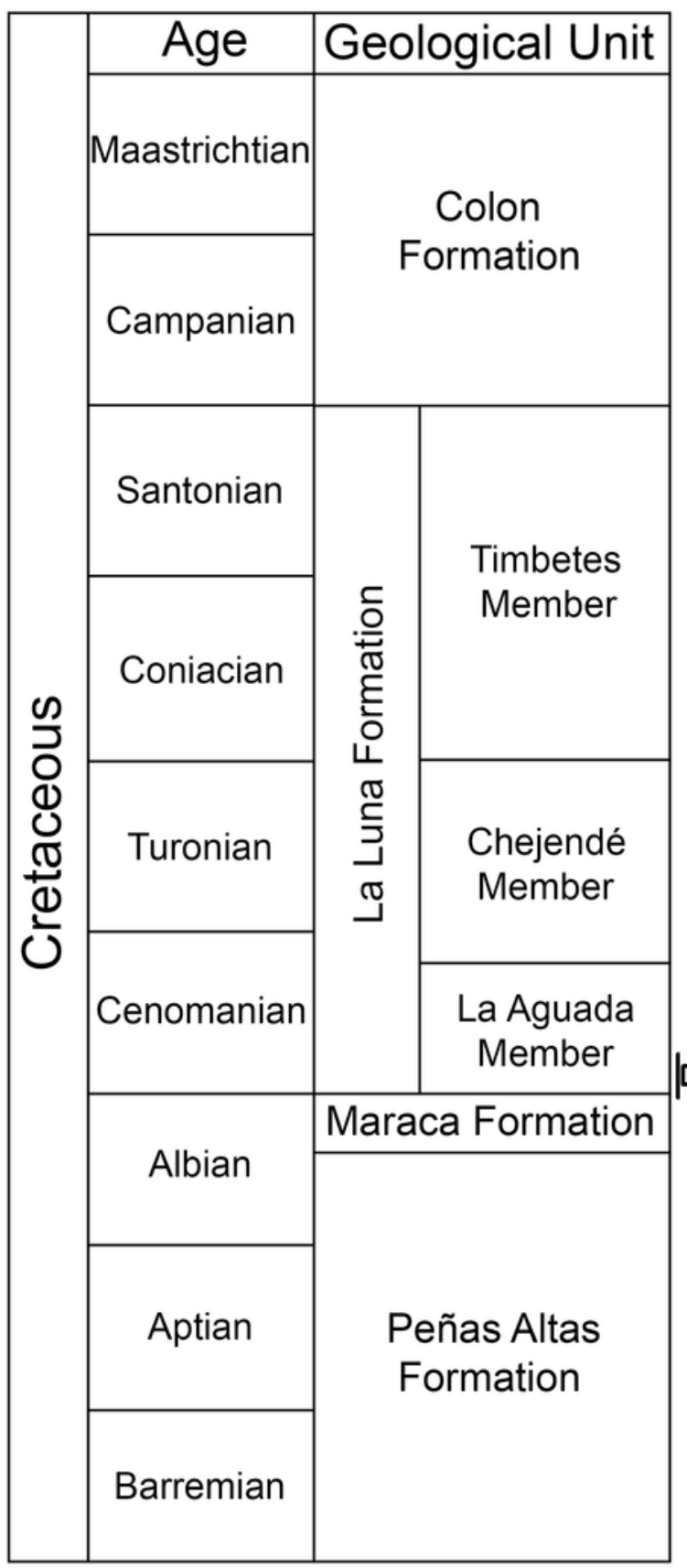

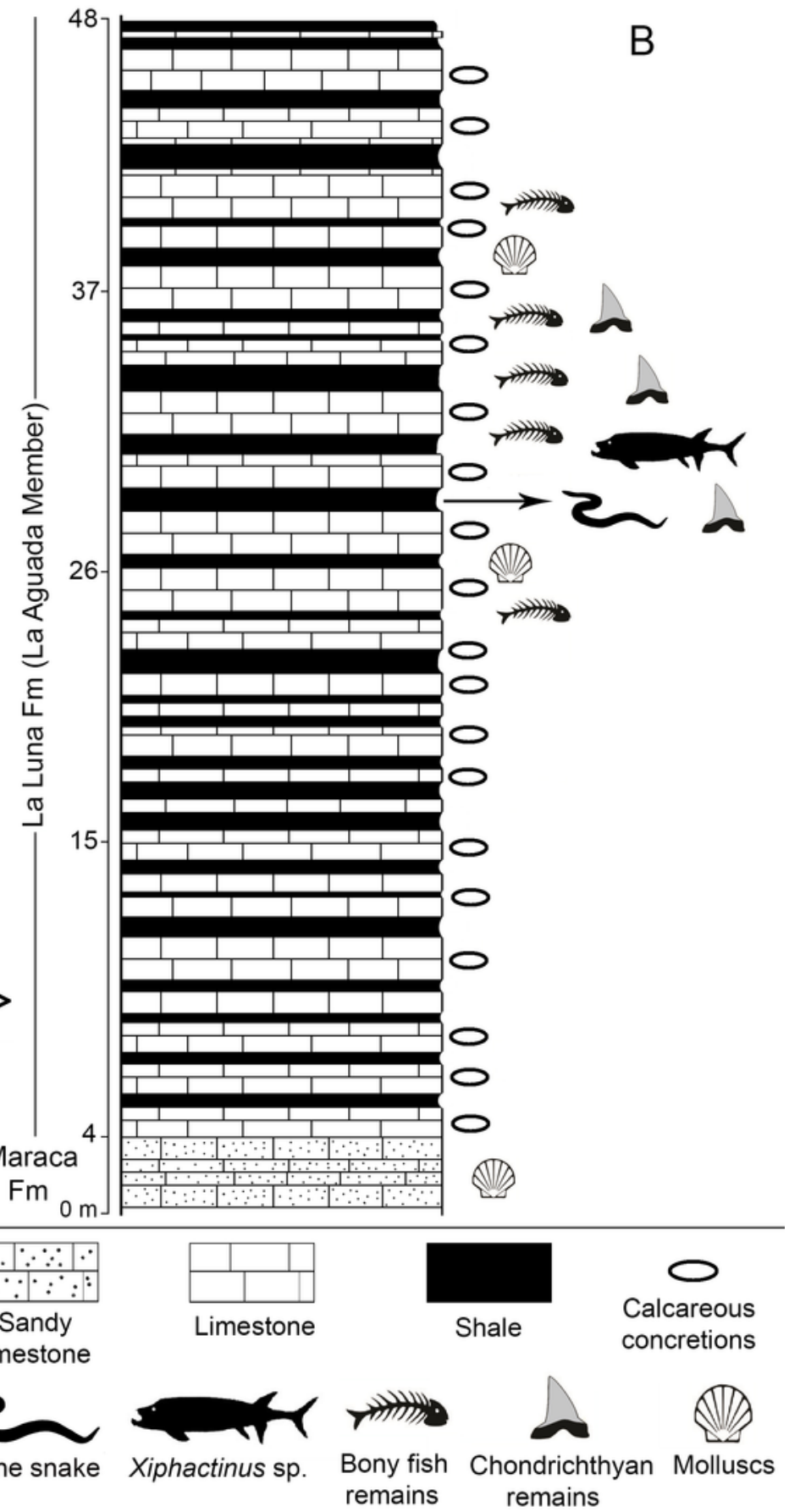


3

Outcrops of the La Aguada Member in the Cementos Andinos quarry.

A. Fossiliferous strata; B. Strata with calcareous concretions; C, D. Discoidal calcareous concretions. 

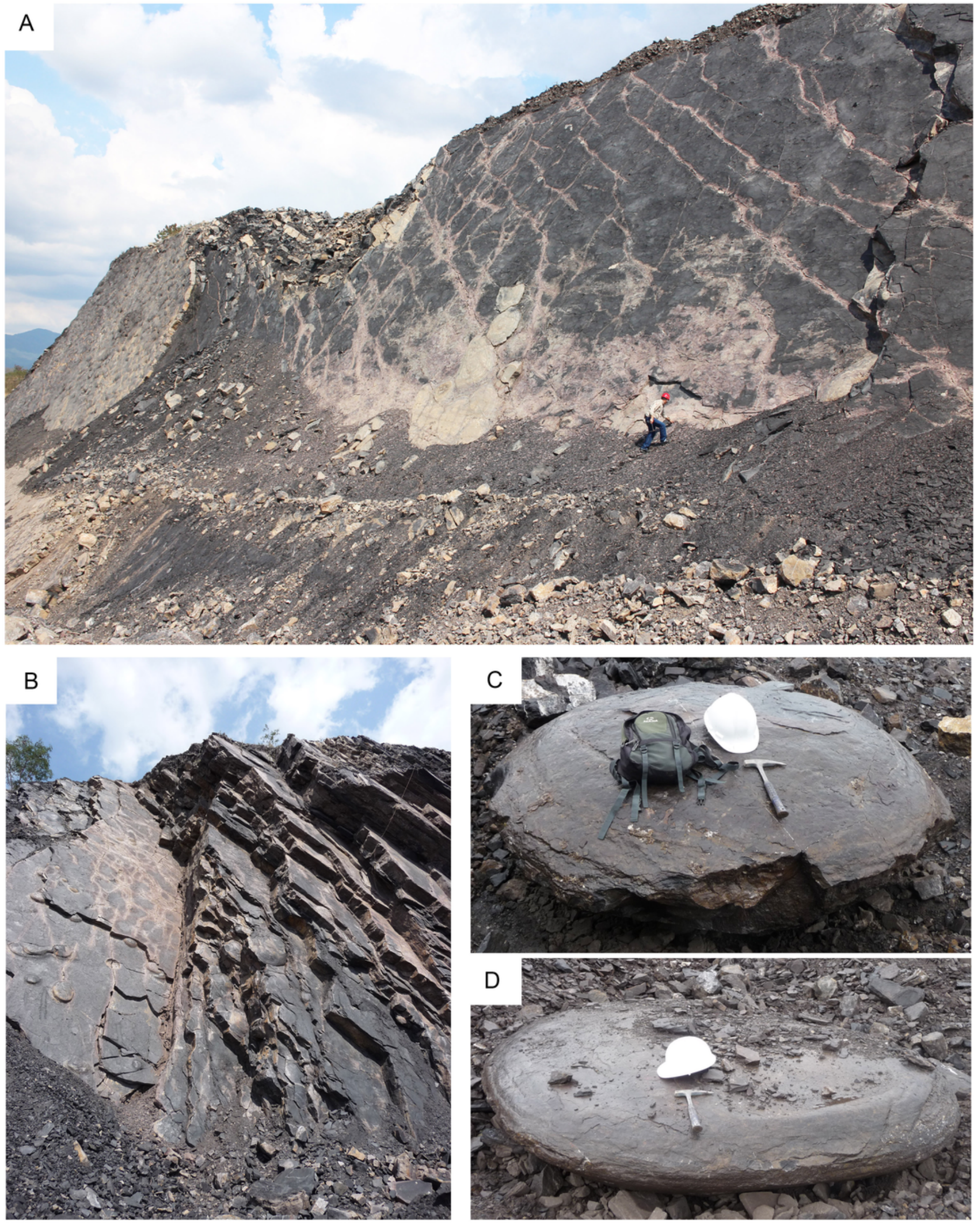
4

Holotype of Lunaophis aquaticus

Holotype of Lunaophis aquaticus. MNCN-1827-A, isolated precloacal vertebra. Anterior (A), left lateral (B), dorsal (C), and ventral (D) views. [p]

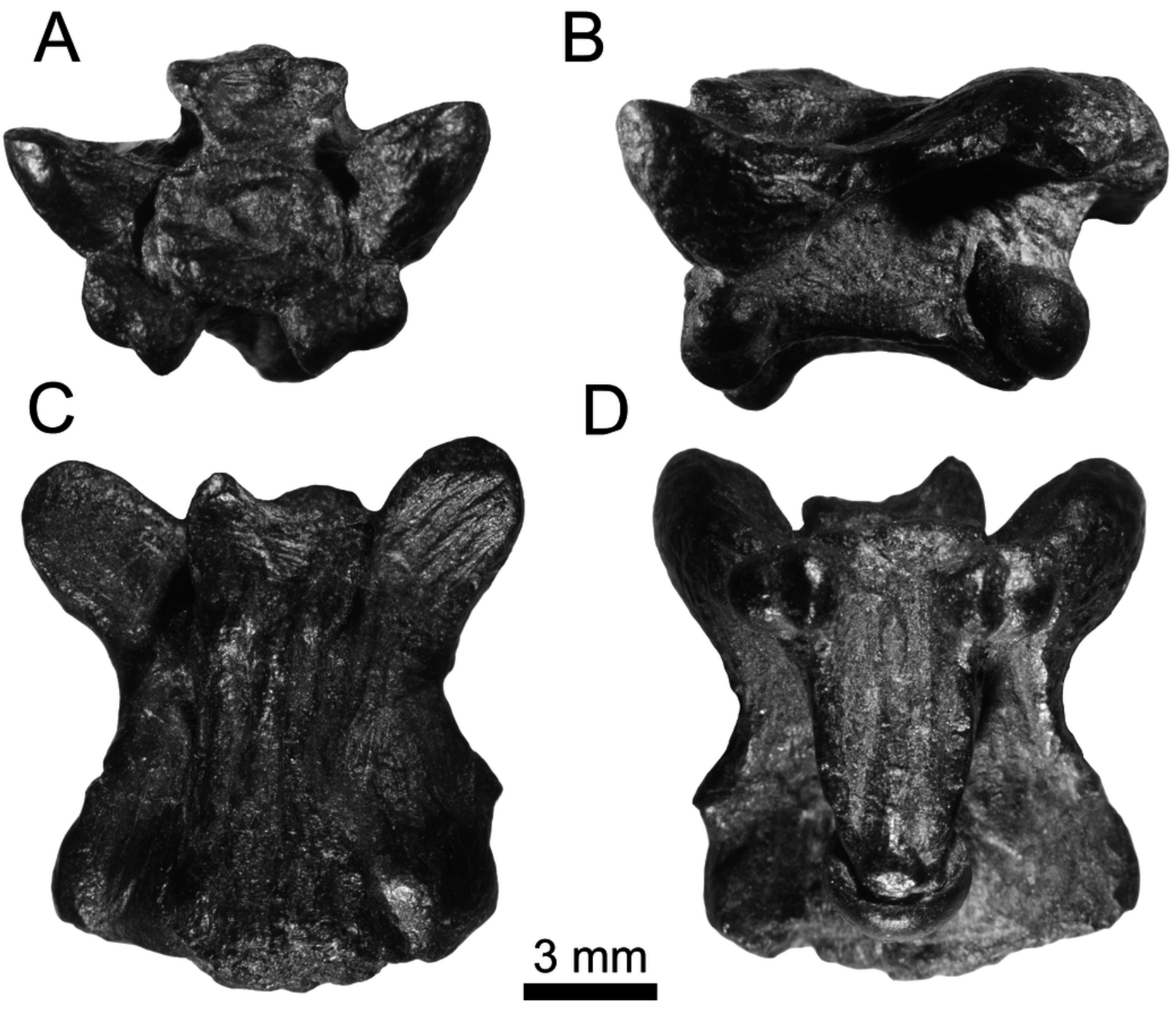


5

Holotype of Lunaophis aquaticus

Holotype of Lunaophis aquaticus, isolated precloacal vertebrae. A-B, MNCN-1827-B; C-D, MNCN-1827-C; E-F, MNCN-1827-D; G-H, MNCN-1827-E. Dorsal (A, C, E, G), and ventral (B, D, $\mathrm{F}, \mathrm{H})$ views. 
A

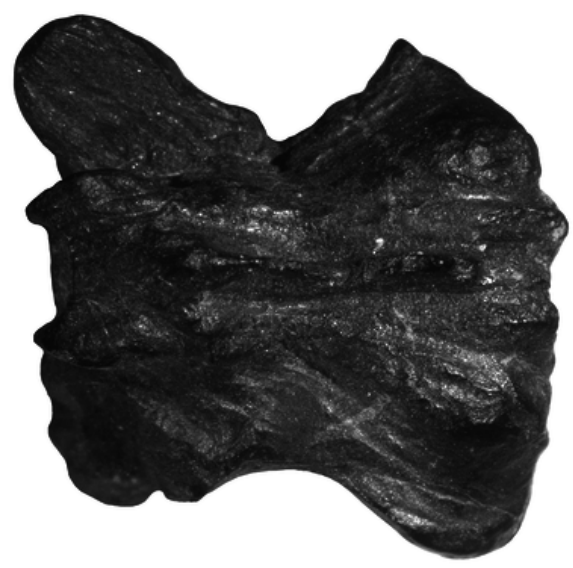

$Q$

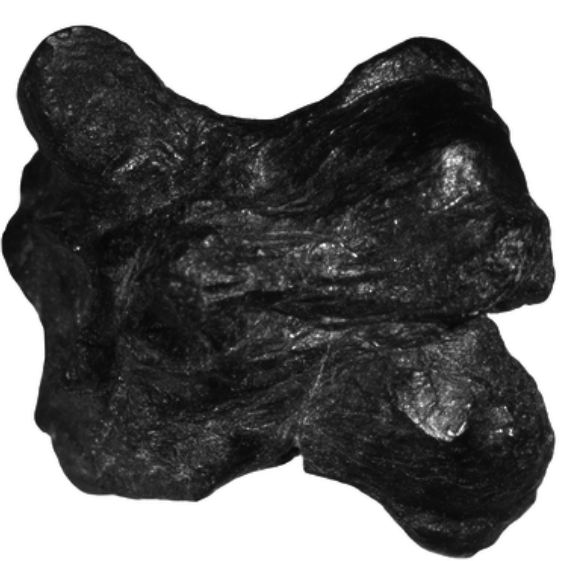

E

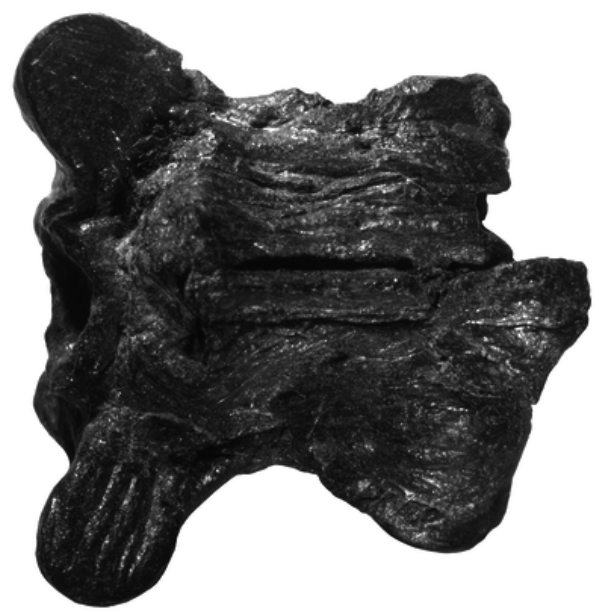

G

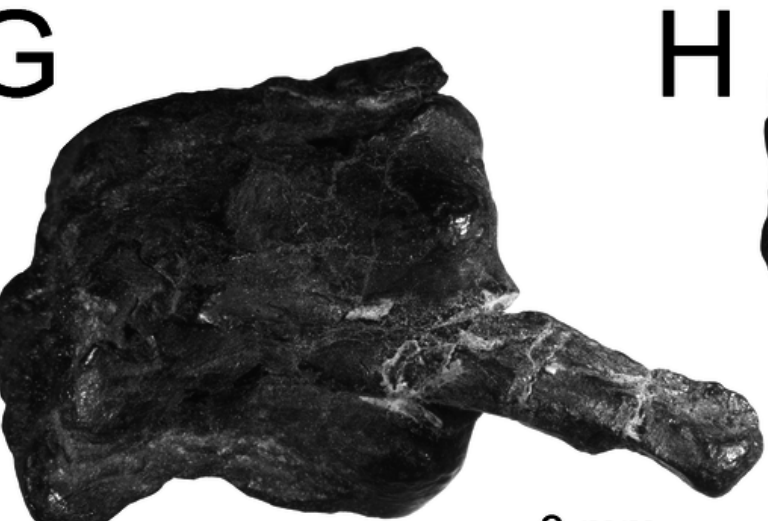

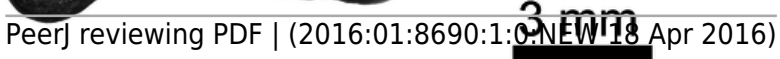

D

$\mathrm{F}$
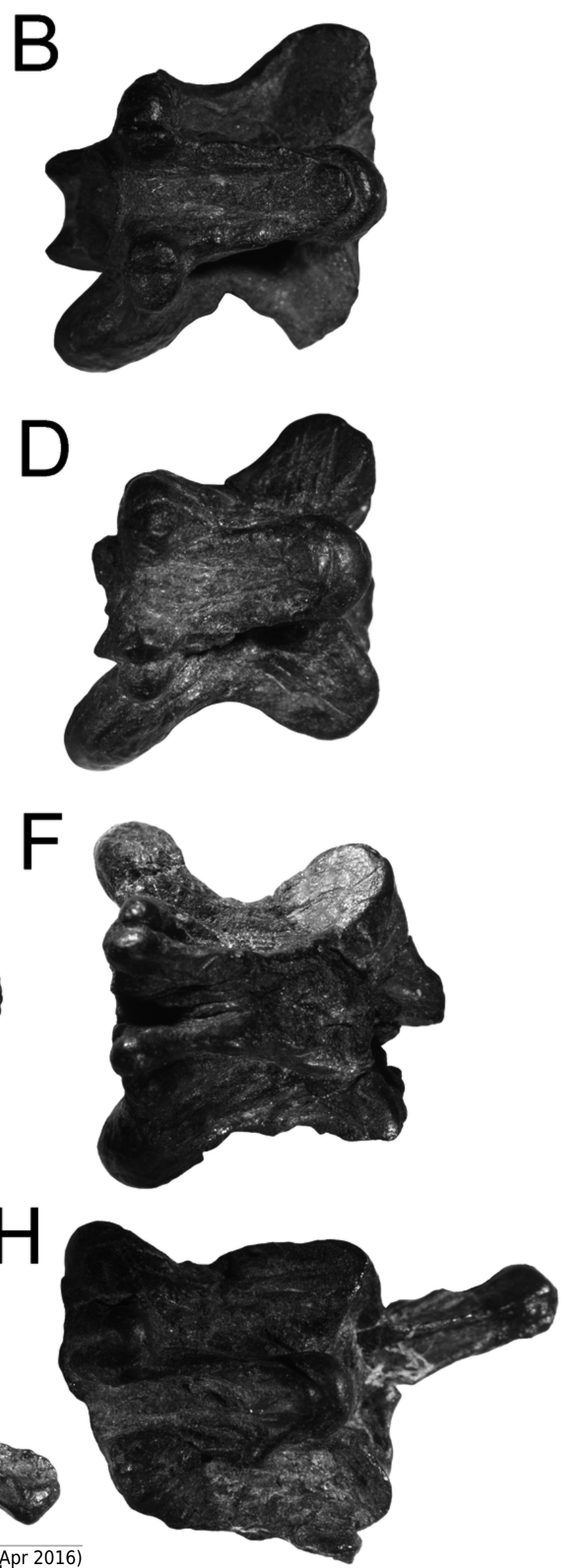


\section{6}

Holotype of Lunaophis aquaticus

Holotype of Lunaophis aquaticus. MNCN-1827-F, articulated precloacal vertebrae. Dorsal (A) and ventral $(B)$ views.

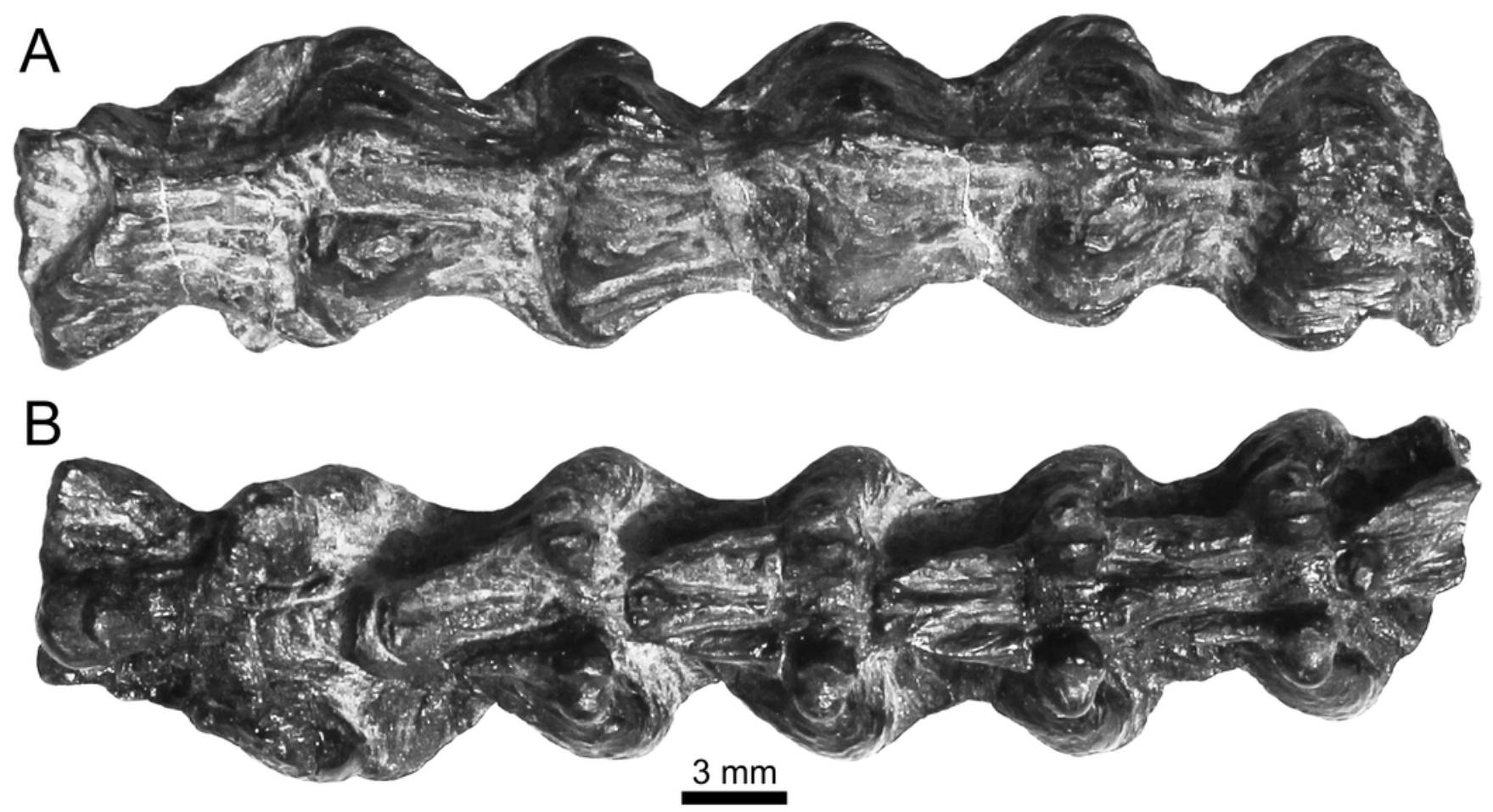




\section{7}

Holotype of Lunaophis aquaticus

Holotype of Lunaophis aquaticus. MNCN-1827-A, isolated precloacal vertebra. Anterior (A), posterior $(B)$, dorsal $(C)$, ventral $(D)$, right lateral $(E)$, left lateral $(F)$, dorsoposterior $(G)$, and posterolateral (H) views; co, condyle; ct, cotyle; hk, haemal keel; izr, interzygapophyseal ridge; na, neural arch; pd, paradiapophysis; plf, paralymphatic fossa; po, postzygapophysis; pr, prezygapophysis; sbr, subcentral ridge; zg, zygosphene.

*Note: Auto Gamma Correction was used for the image. This only affects the reviewing manuscript. See original source image if needed for review.

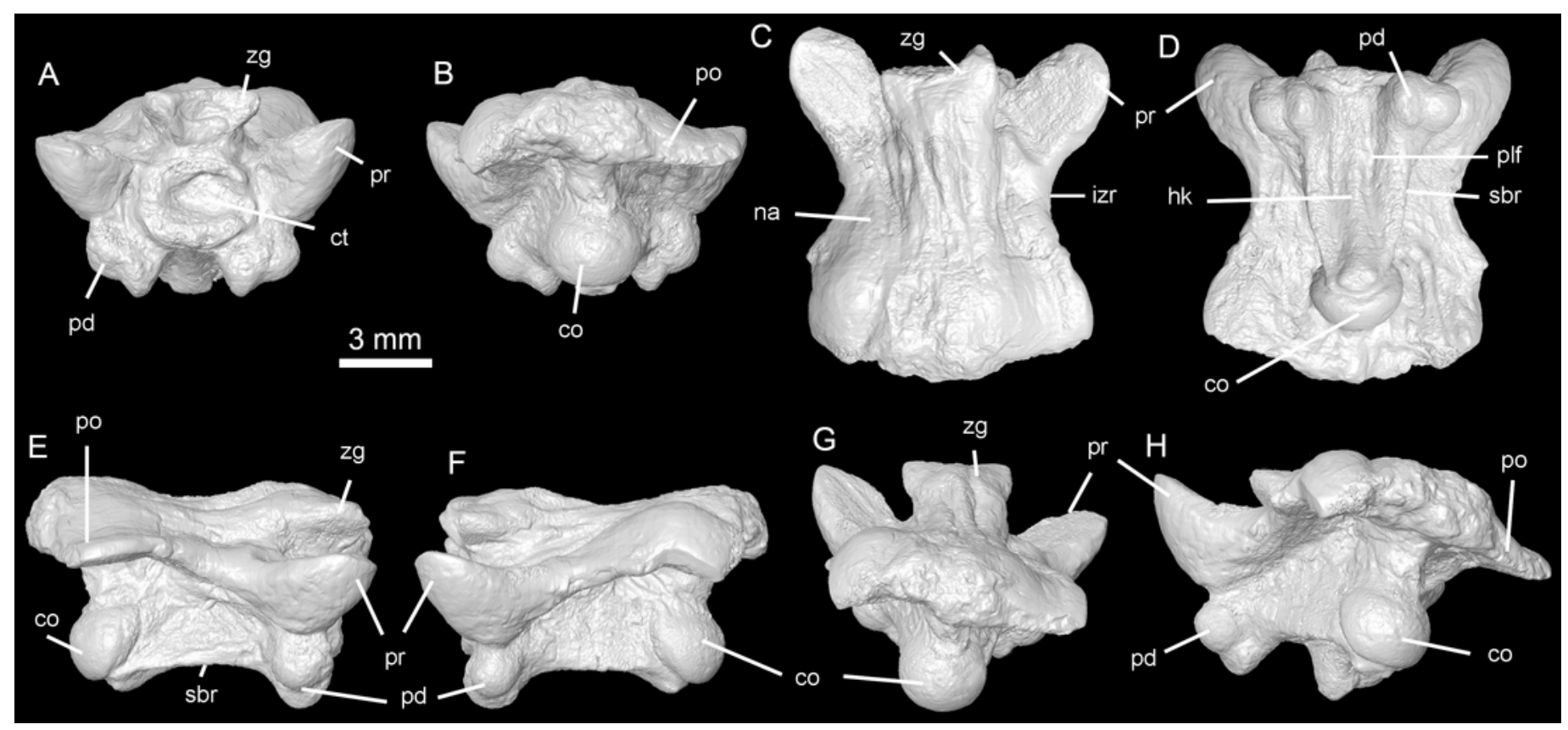




\section{8}

Holotype of Lunaophis aquaticus

Holotype of Lunaophis aquaticus. MNCN-1827-B, isolated precloacal vertebra. Dorsal (A), ventral (B), left lateral (C), and right lateral (D) views; co, condyle; hk, haemal keel; na, neural arch; ns, neural spine; pd, paradiapophysis; plf, paralymphatic fossa; po, postzygapophysis; pr, prezygapophysis; sbr, subcentral ridge; zg, zygosphene.

*Note: Auto Gamma Correction was used for the image. This only affects the reviewing manuscript. See original source image if needed for review.
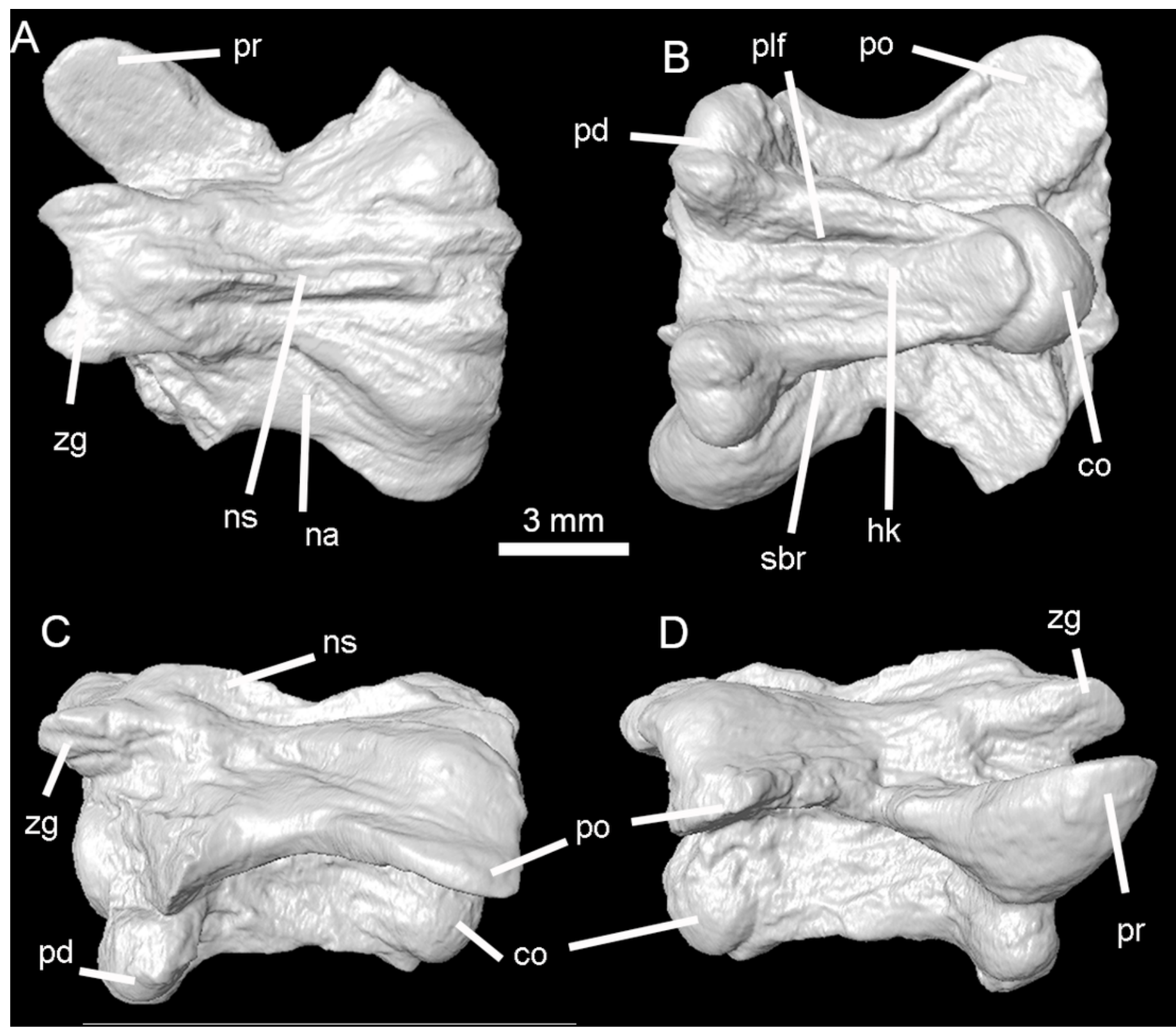
9

Holotype of Lunaophis aquaticus.

Holotype of Lunaophis aquaticus. A-D, MNCN-1827-C, isolated precloacal vertebra; E-H, MNCN-1827-D, isolated precloacal vertebra; I-L, MNCN-1827-E, isolated anterior vertebra. Dorsal $(A, E, I)$, ventral $(B, F, J)$, left lateral $(C, G, K)$, and right lateral $(D, H, L)$ views; $c 0$, condyle; na, neural arch; ns, neural spine; pd, paradiapophysis; po, postzygapophysis; pr, prezygapophysis; sbr, subcentral ridge.

*Note: Auto Gamma Correction was used for the image. This only affects the reviewing manuscript. See original source image if needed for review. 

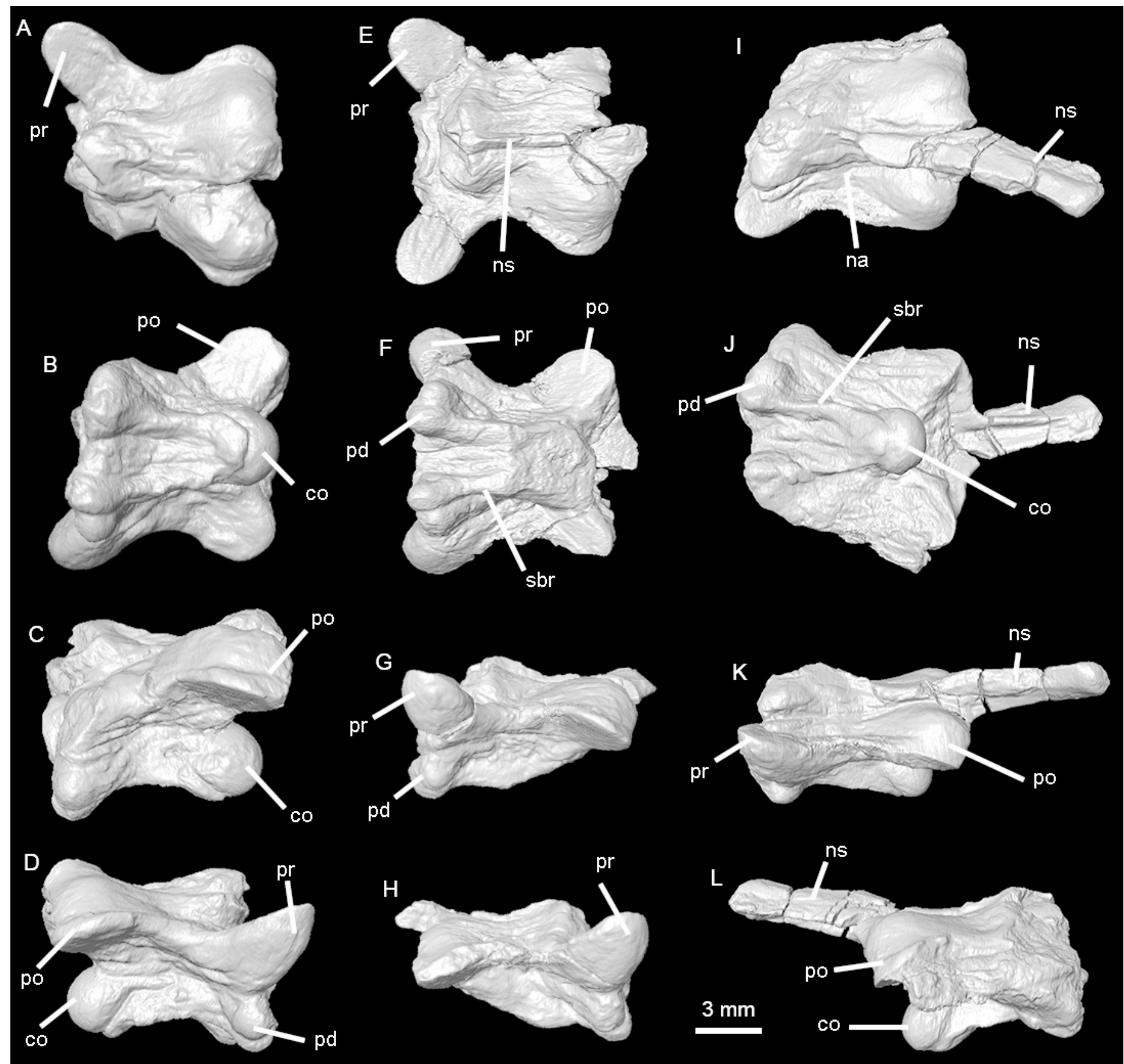


\section{0}

Holotype of Lunaophis aquaticus.

Holotype of Lunaophis aquaticus. A-D, MNCN-1827-F, articulated precloacal vertebrae; E-H, MNCN-1827-G, scarcely preserved vertebral fragment. Dorsal $(A, E$,$) , ventral (B, F)$, left lateral (C, G), and right lateral (D, H) views; hk, haemal keel; na, neural arch; ns, neural spine; pd, paradiapophysis; po, postzygapophysis; pr, prezygapophyis.

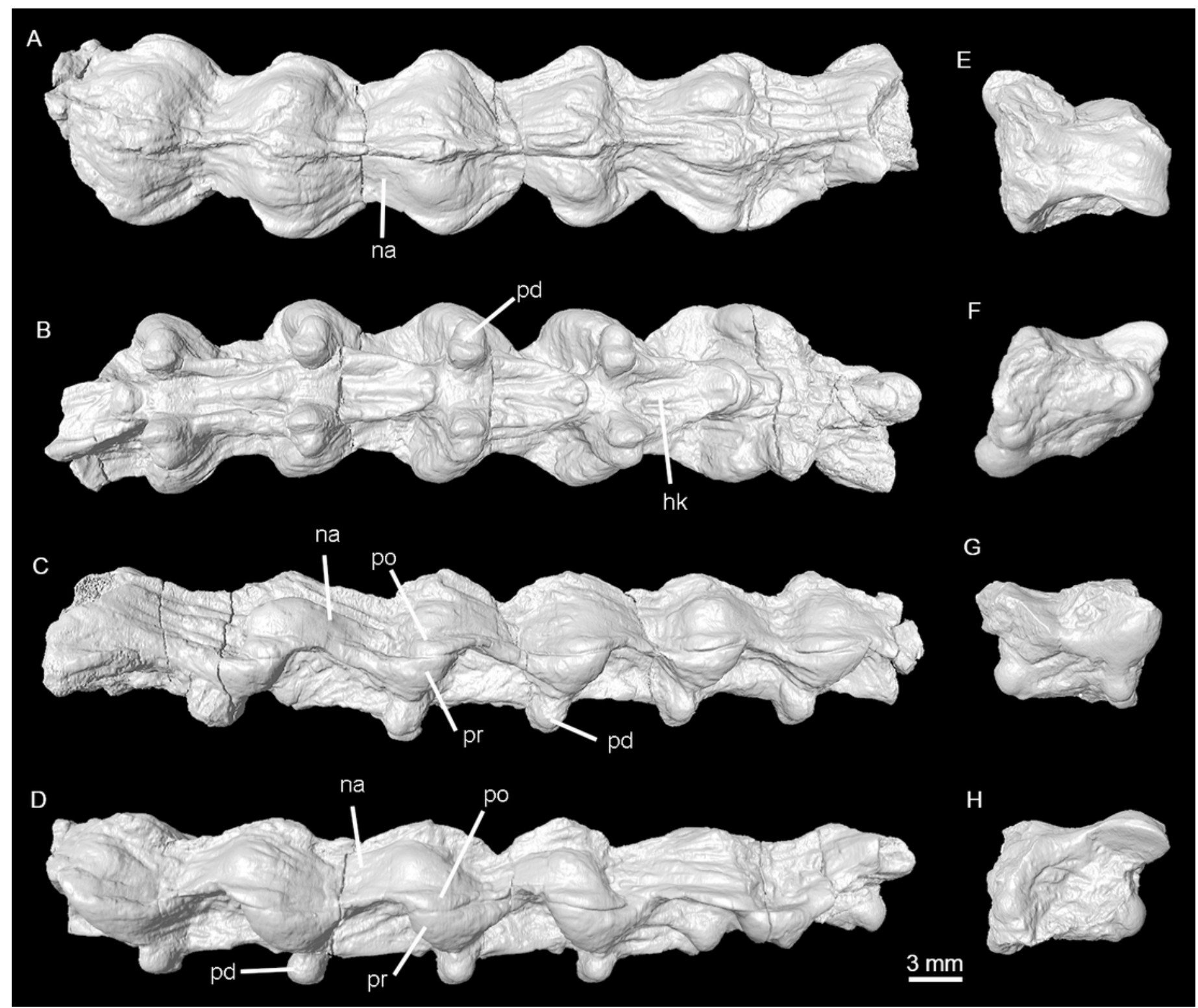




\section{1}

Longitudinal (A) and transverse (B) $\mu \mathrm{CT}$ sections through specimen MNCN-1827-F showing pachyostotic, thickened cortical bone; with section positions shown in $\mathrm{C}$.

Abbreviations: tcb, thickened cortical bone; nc, neural canal.

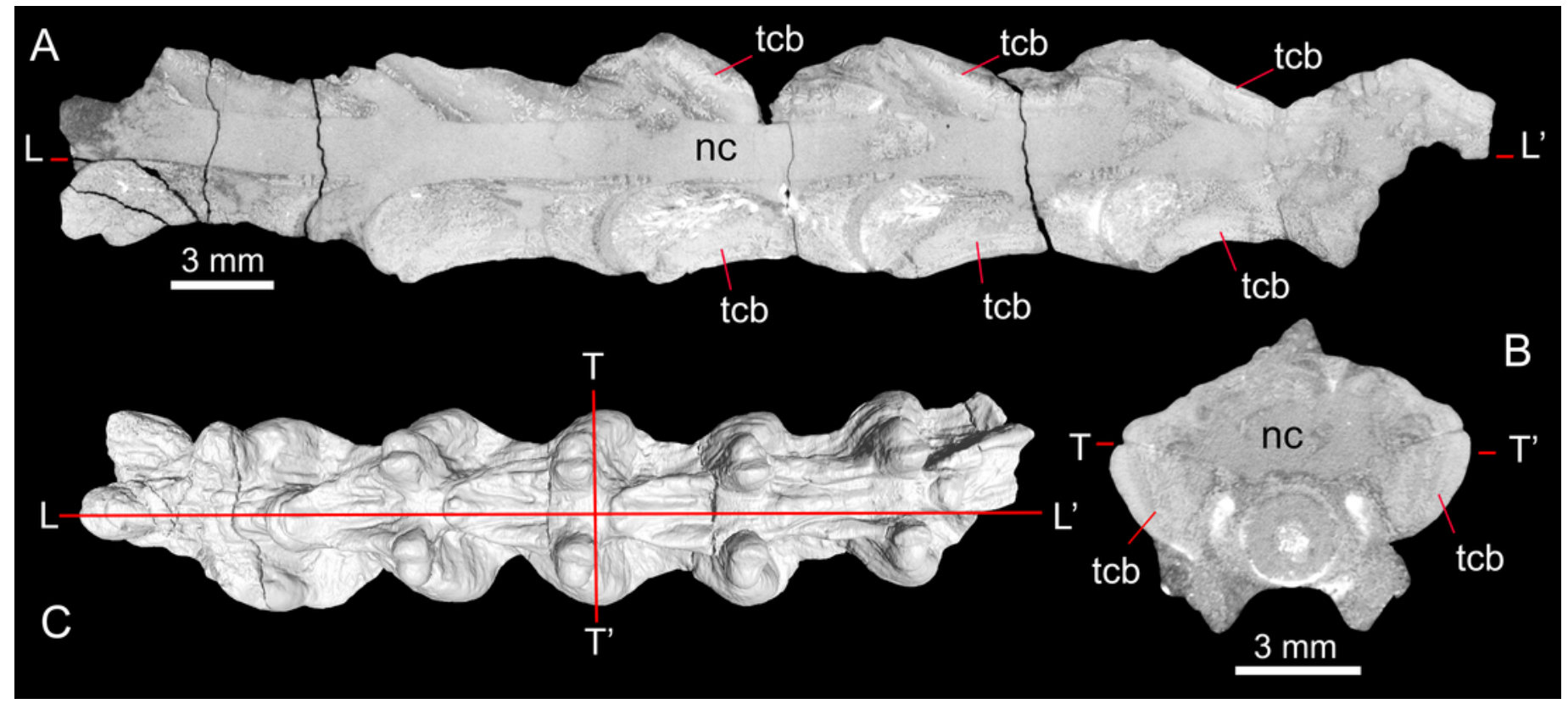




\section{Table $\mathbf{1}$ (on next page)}

Measures available on vertebrae of Lunaophis aquaticus

Abbreviations: $\mathrm{Cl}$, centrum length; cow, condyle wide; cth, cotyle high; $c t w$, cotyle wide; $\mathrm{H}$, high of the vertebra; nal, neural arch length; naw, neural arch wide; po-po, distance between postzygapophyses; prl, prezygapophyses length; prw, prezygapophysis wide; pr-po, distance between pre- and postzygapophyses of the same side; pr-pr, distance between prezygapophyses; zgh, zygosphene high; zgw, zygosphene wide. 
1 Table 1. Measures available on vertebrae of MNCN-1827.

\begin{tabular}{|c|c|c|c|c|}
\hline $\begin{array}{l}\text { Measures } \\
\text { (in } \mathrm{mm} \text { ) }\end{array}$ & MNCN-1827-A & MNCN-1827-B & MNCN-1827-C & MNCN-1827-D \\
\hline $\mathrm{cl}$ & 8.44 & 8.00 & 7.62 & - \\
\hline cow & 3.00 & 2.86 & 3.00 & - \\
\hline cth & - & 2.82 & 3.00 & 2.58 \\
\hline ctw & - & 3.10 & 3.18 & 3.00 \\
\hline $\mathrm{H}$ & 6.34 & 5.70 & 7.16 & - \\
\hline naw & 6.44 & 6.18 & 6.34 & 6.84 \\
\hline nal & 10.16 & 9.22 & - & - \\
\hline po-po & - & 9.62 & - & - \\
\hline prl & 3.56 & 3.34 & 3.50 & 3.26 \\
\hline prw & 2.56 & 2.76 & 2.40 & 2.84 \\
\hline pr-po & 9.52 & - & 9.20 & 9.14 \\
\hline pr-pr & 10.00 & - & - & 10.94 \\
\hline $\mathrm{zgh}$ & - & 0.40 & - & - \\
\hline zgw & 3.66 & 3.60 & - & - \\
\hline
\end{tabular}

2 